\title{
Article
}

Jianlin Chen*

\section{Bias and Religious Truth-Seeking in Proselytization Restrictions: An Atypical Case Study of Singapore}

\begin{abstract}
Proselytisation restrictions are typically subjected to two objections. First, these restrictions curtail religious liberty and impede religious truth-seeking. Second, these restrictions tend to favour politically dominant religions and discriminate against minority religions. The restrictions on offensive religious propagation in Singapore thus present an interesting departure in which sanctioned religions are not politically marginalised religions, whereas protected religions include numerical minority religions that are socially, economically, and politically disadvantaged. This article utilises the atypical case study of Singapore to highlight the limitations of the two typical objections toward proselytisation restrictions. In particular, the emphasis on religious truth-seeking underpinning these objections is premised upon a distinct set of religious worldviews not shared by the majority of religions in Singapore. This article posits that if religious truthseeking is no longer the accepted normative goal, then there may be circumstances in which some limited and even-handed restrictions on offensive religious propagation are sufficiently justified on the grounds of social peace and harmony.
\end{abstract}

Keywords: freedom of religion, Proselytization restrictions, religious harmony, Singapore

*Corresponding author: Jianlin Chen, Department of Law, University of Hong Kong, Cheng Yu Tung Tower, Pok Fu Lam, Hong Kong, E-mail: jianlin@hku.hk

\section{INTRODUCTION}

Restrictions on religious propagation, or proselytisation, are controversial. In particular, two major objections are frequently raised against such legal

Assistant Law Professor (University of Hong Kong), JSD Candidate (University of Chicago), LLM (University of Chicago), LLB (University of Singapore). Admitted to the bar in New York and Singapore. 
restrictions. First, given the religious duty inherent in many missionary religions to evangelise and spread their faith, ${ }^{1}$ these restrictions not only curtail the religious liberty of these religious adherents but also impede informed religious choice. ${ }^{2}$ Second, notwithstanding the various purported justifications of social peace underpinning these restrictions, ${ }^{3}$ the normative desirability of these restrictions is frequently compromised by the fact that these restrictions tend to favour dominant religions and are often one-sided in nature. ${ }^{4}$

Religious propagation is restricted in Singapore. In particular, "offensive" religious propagation is subjected to an array of legal and quasi-legal sanctions. ${ }^{5}$ Worrisome from the perspective of religious liberty and religious free discourse, recent incidents in Singapore revealed that "offense" is given a broad and crude interpretation. Private individuals have been sentenced to imprisonment for sending evangelical materials to Muslims. ${ }^{6}$ These materials, while censorious toward Islam, fall short of religious hate speech. ${ }^{7}$ Critical commentaries by two Christian pastors on the religious practices of Buddhism and Taoism have also prompted intervention from the Singapore government via the Internal Security

1 Timothy L. Hall, "Toleration and Dogmatism: The Contribution of Baptists to Law" in Robert F. Cochran, Jr. ed., Faith and Law: How Religious Traditions from Calvinism to Islam View American Law (New York University Press, 2008) at 77, 85; Barry A. Kosmin \& Ariela Keysar, Religion in a Free Market (Paramount Market Publishing, 2006) at 11; Peter Radan, "International Law and Religion: Article 18 of the International Covenant on Civil and Political Rights" in Peter Radan et al. eds., Law and Religion: God, the State and the Common Law (Routledge, 2005) at 9, 17; R. Andrew Chesnut, Competitive Spirits: Latin America's New Religious Economy (Oxford University Press, 2003) at 11.

2 Rosalind I.J. Hackett, "Revising Proselytization in the Twenty-first Century" in Rosalind I.J. Hackett ed., Proselytization Revisited: Rights Talk, Free Markets and Culture Wars (Equinox, 2008) at 1, 3-4; M. Todd Parker, "The Freedom to Manifest Religious Belief: An Analysis of the Necessity Clauses of the ICCPR and the ECHR” (2006) 17 Duke J. Comp. \& Int'l L. 91, 91-92. See infra II.B.

3 Li-ann Thio, "Contentious Liberty: Regulating Religious Propagation in a Multi-Religious Secular Democracy” (2010) 2010 S.J.L.S. 484, 488-493. See Grace Y. Kao, "The Logic of Antiproselytization, Revisited” in Rosalind I.J. Hackett ed., Proselytization Revisited: Rights Talk, Free Markets and Culture Wars (Equinox, 2008) at 76 (discussing and critiquing the various arguments supporting restrictions on proselytization).

4 Examples include Malaysia, Greece and India: see infra II.A.

5 Infra III.B.

6 Public Prosecutor v. Ong Kian Cheong [2009] SGDC 163, at para. 28 \& 33 (hereinafter "Ong Kian Cheong case”); Khushwant Singh, “Jailed for 'wounding feelings' of Muslims” The Straits Times (7 August 2010). See infra III.C.

7 Infra IV.A. See generally Zhong Zewei, "Racial and Religious Hate Speech in Singapore: Management, Democracy, and the Victim's Perspective” (2009) 27 Sing. L. Rev. 13 (discussing the Singapore incidents from the perspective of hate speech). 
Department ("ISD"), a government authority empowered with the dreaded power of detention without trial under the Internal Security Act. ${ }^{8}$ Echoing the two typical objections of proselytisation restrictions, prominent local constitutional law scholar Li-ann Thio and other legal academics have criticised the impact of restrictions on the Christian minority in Singapore and the censoring of religious propagation that impedes religious liberty and religious truthseeking. ${ }^{9}$

Careful examination of the Singapore legal regime, however, reveals two important nuances that challenge the applicability and normative strengths of these objections. First, contrary to the usual narrative, the sanctioned religion in Singapore is anything but a politically marginalised religious community, whereas protected religions include numerical minority religions that are socially, economically, and politically disadvantaged. Singapore is a pluralistic religious society that includes a diverse spectrum of religious worldviews and has no dominant religion. According to the most recent 2010 census, the religious composition of Singapore includes Buddhism (33.3\%), Christianity (18.3\%), Islam (14.7\%), Taoism (10.9\%), Hinduism (5.1\%), and Others (0.7\%), with $17.0 \%$ reporting no religious affiliation. ${ }^{10}$ Although the sanctioned parties in all recent incidents are Christians, commentators have observed that Christians in Singapore exert "an influence, politically, socially and economically, far greater than the number they represent in the population."11 In contrast, the "protected" religions of Taoism and Islam are numerical minorities that are significantly underrepresented in various socio-economic indicators. ${ }^{12}$

Second, there is a divergence in attitudes toward proselytisation and religious truth-seeking among the major religions in Singapore's diverse religious

8 Tai-Heng Cheng, “The Central Case Approach to Human Rights: Its Universal Application and the Singapore Example” (2004) 13 Pac. Rim L. \& Pol'y J. 257, 270. For discussion of the Internal Security Act, see infra III.B.2.d.

9 Li-ann Thio, "Contentious Liberty: Regulating Religious Propagation in a Multi-Religious Secular Democracy” (2010) 2010 S.J.L.S. at 489 \& 506-508; Jaclyn Ling-Chien Neo, "Seditious in Singapore! Free Speech and the Offence of Promoting Ill-Will and Hostility Between Different Racial Groups" (2011) 2011 S.J.L.S. 351, 364-366. See infra V.

10 Singapore Department of Statistics, Census of Population 2010 Statistical Release 1: Demographic Characteristics, Education, Language and Religion (2011) at 13.

11 Mathew Mathews, "Accommodating Relationship: The Church and State in Singapore” in Julius Bautista \& Francis Khek Gee Lim eds., Christianity and the State in Asia (Routledge, 2009) at 184, 187; Jean DeBernardi, “Asia's Antioch: Prayer and Proselytism in Singapore” in Rosalind I.J. Hackett ed., Proselytization Revisited: Rights Talk, Free Markets and Culture Wars (Equinox, 2008) at 252, 257. Infra V.A.

12 Infra V.A. 
landscape. The Buddhist, Taoist, Hindu, and Muslim communities in Singapore do not treat evangelism with the same emphasis and reverence as Christianity. ${ }^{13}$ Religious truth-seeking is also not of particular concern for Buddhists, Taoists, and Hindus in Singapore. ${ }^{14}$ While the Singapore restrictions on offensive religious propagation may seemingly reflect a "postmodern" aversion towards religious critiques of other religions, ${ }^{15}$ the restrictions are in fact consistent to the religious outlooks of the majority of the population.

This article utilises the case study of Singapore to highlight the limitations of the two typical objections toward proselytisation restrictions. The controversial issue of proselytisation is often framed as a balance between the individual's right to free speech and religious liberty and the State's interest in the preservation of social harmony. ${ }^{16}$ Echoing the "marketplace of ideas" justification of free speech, ${ }^{17}$ offensive and harmful religious propagation are protected from government sanctions as a means of facilitating the emergence of religious truth through free competition among the different religions. ${ }^{18}$ Yet the case of Singapore demonstrates that proselytisation restrictions are not always the result of oppression by dominant religious majorities, and may genuinely reflect a different religious assumption. Without the broad acceptance of religious truth seeking as a normative goal, the case for tolerating offensive religious propagation is deprived of an otherwise compelling justification. Moreover, while some local academics have argued that restrictions on religious propagation is counterproductive to social

13 Infra V.B.

14 Infra V.C.

15 Li-ann Thio, “Contentious Liberty: Regulating Religious Propagation in a Multi-Religious Secular Democracy” (2010) S.J.L.S. at 508-509.

16 Jaclyn Ling-Chien Neo, "Seditious in Singapore! Free Speech and the Offence of Promoting Ill-Will and Hostility Between Different Racial Groups” (2011) S.J.L.S. at 354; Li-ann Thio, "Contentious Liberty: Regulating Religious Propagation in a Multi-Religious Secular Democracy” (2010) S.J.L.S at 493.

17 Lawrence Rosenthal, "First Amendment Investigations and the Inescapable Pragmatism of the Common Law of Free Speech" (2011) 86 Ind. L.J. 1, 61-62 \& 61 n. 288; Steven G. Gey, “The First Amendment and the Dissemination of Socially Worthless Untruths" (2008) 36 Fla. St. U.L. Rev. 1, 6-9; Geoffrey R. Stone et al., Constitutional Law, 5th ed. (Aspen Publishers, 2005) at 1054-1056; William P. Marshall, “Truth and Religion Clauses” (1994) 43 DePaul L. Rev. 243, 256. 18 Daniel O. Conkle, "Religious Truth, Pluralism, and Secularization: The Shaking Foundations of American Religious Liberty” (2011) 32 Cardozo L. Rev. 1755, 1757-1762; Li-ann Thio, "Contentious Liberty: Regulating Religious Propagation in a Multi-Religious Secular Democracy” (2010) S.J.L.S. at 493; M.H. Ogilvie, "Between Liberté and Égalité: Religion and the State in Canada” in Peter Radan et al. eds., Law and Religion: God, the State and the Common Law (Routledge, 2005) at 134, 154; William P. Marshall, "Truth and Religion Clauses" (1994) 43 DePaul L. Rev. at 255-256. 
harmony, ${ }^{19}$ the actual experience of Singapore indicates that the legal sanctioning of offensive religious propagation provides a legal backdrop that serves as a conducive foundation for inter-religious harmony. ${ }^{20}$

The religious liberty of adherents of evangelical religions to proselytise and propagate their faith should always be an important consideration against any restrictions on these activities. Nonetheless, this article argues that one should not give undue weight to the contested assumption of religious truth-seeking and the doubtful benefits of religious integration when critically analysing proselytisation restrictions in the context of a religiously diverse polity. In particular, this article posits that if a substantial majority of a polity does not share the religious truth-seeking emphasis underpinning the objections of religious truth-seeking, then there may be circumstances in which some limited and even-handed restrictions on religious propagation are sufficiently justified on the grounds of social peace and harmony.

This article is organised into six parts. Part II outlines the two common objections toward proselytisation restrictions. Part III presents the case of Singapore, noting the diverse religious landscape, the wide array of legal tools, and the recent incidents involving offensive religious propagation. Part IV examines the features of the Singapore regime, including the breadth of the restrictions, the implications of the express constitutional right to religious propagation, and the reconciliation between the offenders and the offended with the backdrop of calibrated political management and broad legal sanctions. Part $\mathrm{V}$ addresses critiques of the Singapore regime and provides a tentative defense for limited restrictions. Part VI concludes with observations about the search for overlapping consensus in a religiously pluralistic society.

\section{Objections to proselytisation Restrictions}

Proselytising is the most controversial component of religious freedom ${ }^{21}$ and is subjected to restrictions in many jurisdictions with various justifications. These

19 Jaclyn Ling-Chien Neo, "Seditious in Singapore! Free Speech and the Offence of Promoting Ill-Will and Hostility Between Different Racial Groups” (2011) S.J.L.S. at 371-372; Li-ann Thio, "Contentious Liberty: Regulating Religious Propagation in a Multi-Religious Secular Democracy” (2010) S.J.L.S. at 493.

20 Infra V.C.

21 Anat Scolnicov, The Right to Religious Freedom in International Law (Routledge, 2011) at 198; Li-ann Thio, "Contentious Liberty: Regulating Religious Propagation in a Multi-Religious Secular Democracy" (2010) S.J.L.S. at 484-487; Rosalind I.J. Hackett, "Revising Proselytization in the Twenty-first Century” in Rosalind I.J. Hackett ed., Proselytization Revisited: Rights Talk, Free Markets and Culture Wars (Equinox, 2008) at 3-4. 
justifications typically involve the protection of a religious community, especially in light of allegedly improper religious propagation targeted at vulnerable individuals or foreign imperialistic involvement. ${ }^{22}$ The preservation of social peace, given the potentially disconcerting effects on religious communities, is another common argument. ${ }^{23}$ However, these restrictions are subjected to two major objections. First, the merits of the justifications for proselytisation restrictions are undercut by the fact that these restrictions tend to be one-sided in favour of politically dominant religions. Second, these restrictions unduly infringe religious liberty and impede religious truth-finding.

\section{A. Discriminatory Nature}

The design and enforcement of the restrictions on religious propagation are typically skewed toward protecting only the politically dominant religious communities. For example, the religious liberty clause of Malaysia's Constitution expressly allows the State to control or restrict religious propagation, but this principle only applies to persons professing the religion of Islam. ${ }^{24}$ This approach has produced laws and court cases that sanction proselytisation attempts directed towards the majority Muslim population and effectively curtailed the ability of Muslims to switch to other religions. ${ }^{25}$ The Greek criminalisation of proselytisation theoretically provides protection from improper proselytisation to members of all religions. ${ }^{26}$ However, echoing the state establishment of the Greek Orthodox Church, which includes a monopoly of public

22 Anat Scolnicov, The Right to Religious Freedom in International Law (Routledge, 2011) at 198199; Grace Y. Kao, "The Logic of Anti-proselytization, Revisited" in Rosalind I.J. Hackett ed., Proselytization Revisited: Rights Talk, Free Markets and Culture Wars (Equinox, 2008).

23 Li-ann Thio, "Contentious Liberty: Regulating Religious Propagation in a Multi-Religious Secular Democracy” (2010) S.J.L.S. at 490-493 (noting but not endorsing the argument).

24 Art. 11(4), Constitution (Malaysia) ("State law and in respect of the Federal Territories of Kuala Lumpur and Lubuan, federal law may control or restrict the propagation of any religious doctrine or belief among persons professing the religion of Islam.”).

25 See Nurjaanah Abdullah @ Chew Li Hua, "Legislating Faith in Malaysia” [2007] S.J.L.S. 264. 26 The criminalised proselytisation is defined as "any direct or indirect attempt to intrude on the religious beliefs of a person of a different religious persuasion (eterodoxos), with the aim of undermining those beliefs, either by any kind of inducement or promise of an inducement or moral support or material assistance, or by fraudulent means or by taking advantage of the other person's inexperience, trust, need, low intellect or naivete.”: section 4, Greek Law No. 1363/68 (amended by Law No. 1672/39). 
and private mass media, and religious indoctrination in school, ${ }^{27}$ the proselytisation laws only protect the adherents of the Greek Orthodox religion, ${ }^{28}$ which constitute nearly $98 \%$ of the country's population. ${ }^{29}$ In the Indian state of Arunachal Pradesh, restrictions are placed on missionary activities by and conversions to "non-indigenous religions" such as Christianity. However, no limitation is placed on Hindu missionary activity. Indeed, reconversion to Hinduism is encouraged by the State. ${ }^{30}$ A similar pattern of bias occurs in Sri Lanka between the majority Buddhist population and the Christian minority. ${ }^{31}$

In a similar vein, laws on blasphemy (or religious insult) typically only protect certain privileged religions. Prior to abolition in $2008,{ }^{32}$ the English common laws on blasphemy sanctioned religious insults, but only if the insults involved Christianity, specifically the doctrines and practices of the Church of England as the form of religion established by law in England. ${ }^{33}$ Indeed, the English court "refused to develop the common law to protect Muslim feelings" in the high-profile incident of Salman Rushdie's The Satanic Verses. ${ }^{34}$ Blasphemy

27 “Greece” in U.S. Department of State, International Religious Freedom Report (July-December 2010), online: <http://www.state.gov/documents/organization/171697.pdf> (last visited 1 February 2013); Kyriakos N. Kyriazopoulos, "Proselytization in Greece: Criminal Offense vs. Religious Persuasion and Equality” (2004) 20 J.L. \& Religion 149, 160.

28 Kyriakos N. Kyriazopoulos, "Proselytization in Greece: Criminal Offense vs. Religious Persuasion and Equality” (2004) 20 J.L. \& Religion at 154-155.

29 "Greece" in U.S. Department of State, Intermational Religious Freedom Report (July-December 2010), online: <http://www.state.gov/documents/organization/171697.pdf> (last visited 1 February 2013).

30 Robert W. Neufeldt, "To Convert or Not to Convert: Legal and Political Dimensions of Conversion in Independent India” in Robert D. Baird ed., Religion and Law in Independent India, 2nd ed. (Manohar, 2005) at 381, 399.

31 Stephen C. Berkwitz, "Religious Conflict and the Politics of Conversion in Sri Lanka" in Rosalind I.J. Hackett ed., Proselytization Revisited: Rights Talk, Free Markets and Culture Wars (Equinox, 2008) at 199, 219.

32 By the Criminal Justice and Immigration Act 2008: Russell Sandberg, Law and Religion (Cambridge University Press, 2011) at 131.

33 Eric Barendt, "Free Speech and Religion: Secular and Religious Perspectives on Truth" in András Sajó ed., Censorial Sensitivities: Free Speech and Religion in a Fundamentalist World (Eleven International Publishing, 2007) at 23, 37; Paul Weller, "Equity, Inclusivity and Participation in a Plural Society: Challenging Establishment of the Church of England” in Peter W. Edge \& Graham Harvey eds., Law and Religion in Contemporary Society (Ashgate, 2000) at 53, 61. See also Russell Sandberg, Law and Religion (Cambridge University Press, 2011) at 131-139 (also discussing how the blasphemy law was in fact policed extra-legally notwithstanding the absence of official prosecution). 34 Eric Barendt, "Free Speech and Religion: Secular and Religious Perspectives on Truth" in András Sajó ed., Censorial Sensitivities: Free Speech and Religion in a Fundamentalist World (Eleven International Publishing, 2007) at 37; Paul Weller, "Equity, Inclusivity and Participation in a Plural Society: Challenging Establishment of the Church of England" in Peter W. Edge \& Graham Harvey eds., Law and Religion in Contemporary Society (Ashgate, 2000) at 61. 
of Islam - and Islam only - is a severe crime in some Muslim-dominant countries, such as Pakistan and Afghanistan..$^{35}$ Blasphemy laws existed and were employed in the early United States against criticisms of and insults to Christianity, but not other religions. ${ }^{36}$ The UN resolutions sponsored by countries from the Organization of the Islamic Conference to call for the illegalisation of defamation of religions also specifically mentioned only Islam and Muslims. $^{37}$

This finding is not surprising. Just as commercial firms would be happy to co-opt the State into establishing and maintaining its market monopoly, religious organisations can be expected to secure their own monopolies via state coercion whenever possible. ${ }^{38}$ Restricting proselytisation by rival competing religions helps to reduce the loss of one's membership and can inhibit the growth of those rival religions. Blasphemy and related laws can also suppress criticisms of one's religion, preserving the façade of legitimacy. American constitutional scholars have argued that such religious captures of the State ultimately do more harm to the religions themselves. ${ }^{39}$ In particular, the lack of religious competition arising from laws entrenching a religious majority can reduce the religiosity of the protected congregation, leaving them adherents in name only. ${ }^{40}$ Nonetheless, Steven H. Shiffrin observed that state repression of rival religions does not necessarily inhibit protected religions, noting, "Christianity flourishes in Central and South America as well as

35 Zahid Hussain, “Islamists Rally in Pakistan” Wall Street Journal (10 January 2011) at A10; Thomas F. Farr, "The Widow's Torment: International Religious Freedom and American National Security in the 21st Century" (2009) 57 Drake L. Rev. 851, 861.

36 Phillip E. Hammond et al., Religion on Trial: How Supreme Court Trends Threaten the Freedom of Conscience in America (Altamira Press, 2004) at 49; James Hitchcock, The Supreme Court and Religion in American Life: Volume I The Odyssey of The Religion Clauses (Princeton University Press, 2004) at 33.

37 Leonard A. Leo et al., "Protecting Religions from 'Defamation': A Threat to Universal Human Rights Standards” (2011) 34 Harv. J.L. \& Pub. Pol’y 769, 771.

38 Larry Witham, Marketplace of the Gods: How Economics Explains Religion (Oxford University Press, 2010) at 115; Rodney Start \& Roger Finke, Acts of Faith: Explaining the Human Side of Religion (University of California Press, 2000) at 199-200.

39 Andrew Koppelman, "Corruption of Religion and the Establishment Clause” (2009) 50 Wm. \& Mary L. Rev. 1831, 1835; Robert F. Cochran, Jr., "Evangelicals, Law, and Abortion” in Robert F. Cochran, Jr. ed., Faith and Law: How Religious Traditions from Calvinism to Islam View American Law (New York University Press, 2008) at 91, 100-101.

40 Larry Witham, Marketplace of the Gods: How Economics Explains Religion (Oxford University Press, 2010) at 148-152; R. Andrew Chesnut, Competitive Spirits: Latin America's New Religious Economy (Oxford University Press, 2003) at 8-10; Michael W. McConnell \& Richard A. Posner, “An Economic Approach to Issues of Religious Freedom” (1989) 56 U. Chicago L. Rev. 1, 55. 
Africa - religions where dictatorships and support for Christianity have often been intertwined." ${ }^{41}$ In any event, the co-opting of state power by politically influential religions to assist one's (and only one's) proselytisation efforts ${ }^{42}$ and/ or resisting others' proselytisation remains common in the U.S. and elsewhere. ${ }^{43}$ This bias in the design and implementation of the law undercuts the normative strengths of the purported justifications for these restrictions.

\section{B. Infringing Religious Liberty and Impeding Religious Truth-Seeking}

Religious liberty is a core human right. ${ }^{44}$ Restrictions on proselytisation pose particular problems to religious liberty because they restrict religious expression, which is otherwise an integral aspect of individual fulfillment and autonomy. ${ }^{45}$ In addition, evangelism is an integral aspect of many religions, such as Christianity ${ }^{46}$

41 Andrew Koppelman, "Corruption of Religion and the Establishment Clause" (2009) 50 Wm. \& Mary L. Rev. at 1902; Robert F. Cochran, Jr., "Evangelicals, Law, and Abortion” in Robert F. Cochran, Jr. ed., Faith and Law: How Religious Traditions from Calvinism to Islam View American Law (New York University Press, 2008) at 101; Steven H. Shiffrin, “The Pluralistic Foundations of the Religion Clauses" (2004) 90 Cornell L. Rev. 9, 43-44.

42 One example is the "Peace Policy" instituted under President Ulysses S. Grant to provide funding for religious organisations that will assist in educating and "civilizing" the Indians. Most of the initial recipients were Protestant missionaries. However, when Catholics and other non-Protestants ended up with bulk of the funding (apportioned according to school enrolments), oppositions to the programs from Protestant community ensued: Phillip E. Hammond et al., Religion on Trial: How Supreme Court Trends Threaten the Freedom of Conscience in America (Altamira Press, 2004) at 35-36.

43 Supra notes 24-37 and accompanying text.

44 Daniel O. Conkle, "Religious Truth, Pluralism, and Secularization: The Shaking Foundations of American Religious Liberty" (2011) 32 Cardozo L. Rev. at 1763; Li-ann Thio, "Courting Religion: The Judge Between Caesar and God in Asian Courts” (2009) 2009 S.J.L.S. 52, 52; M. Todd Parker, "The Freedom to Manifest Religious Belief: An Analysis of the Necessity Clauses of the ICCPR and the ECHR” (2006) 17 Duke J. Comp. \& Int'l L. at 91.

45 Richard M. Esenberg, "Must God be Dead or Irrelevant: Drawing a Circle that Lets Me in" (2009) 18 Wm. \& Mary Bill Rts. J. 1, 37; Lucy Vickers, Religious Freedom, Religious Discrimination and the Workplace (Hart Press, 2008) at 29-40; Li-ann Thio, “Constitutional 'Soft' Law and Management of Religious Liberty and Order: The 2003 Declaration on Religious Harmony” (2004) 2004 S.J.L.S. 414, 417. 46 Barry A. Kosmin \& Ariela Keysar, Religion in a Free Market (Paramount Market Publishing, 2006) at 11; R. Andrew Chesnut, Competitive Spirits: Latin America's New Religious Economy (Oxford University Press, 2003) at 11; Peter Radan, "International Law and Religion: Article 18 of the International Covenant on Civil and Political Rights" in Peter Radan et al. eds., Law and Religion: God, the State and the Common Law (Routledge, 2005) at 17; Timothy L. Hall, "Toleration and Dogmatism: The Contribution of Baptists to Law" in Robert F. Cochran, Jr. 
and Islam. ${ }^{47}$ This emphasis on evangelism is reflected in various types of missionary work and proselytisation activities and is recognised as a fundamental aspect of religious freedom. ${ }^{48}$ Restrictions on proselytisation impede the religious liberty of the adherents of these religions by restricting their ability to fulfill their religious duty of actively spreading their faith.

Moreover, proselytism is necessary to ensure the freedom to adopt and practice religion. ${ }^{49}$ The unimpeded sharing of faith with others helps individuals choose between religions. ${ }^{50}$ Restrictions on proselytisation thus prevent "informed" religious choice. ${ }^{51}$ This is not only a limitation on individual freedom of faith but also an obstruction of the process of religious truth-seeking. The importance of facilitating religious truth-seeking is a common justification for religious liberty. ${ }^{52}$ Robert P. George observed that "[t]he natural law argument

ed., Faith and Law: How Religious Traditions from Calvinism to Islam View American Law (New York University Press, 2008) at 85. C.f., Stephen C. Berkwitz, "Religious Conflict and the Politics of Conversion in Sri Lanka" in Rosalind I.J. Hackett ed., Proselytization Revisited: Rights Talk, Free Markets and Culture Wars (Equinox, 2008) at 212 (noting distinction between evangelical Christian and mainline Christian churches which have "come to deemphasize the call to convert and instead focus on ministering to the already faithful").

47 R. Andrew Chesnut, Competitive Spirits: Latin America's New Religious Economy (Oxford University Press, 2003) at 11; Peter Radan, "International Law and Religion: Article 18 of the International Covenant on Civil and Political Rights" in Peter Radan et al. eds., Law and Religion: God, the State and the Common Law (Routledge, 2005) at 17.

48 Rosalind I.J. Hackett, "Revising Proselytization in the Twenty-first Century" in Rosalind I.J. Hackett ed., Proselytization Revisited: Rights Talk, Free Markets and Culture Wars (Equinox, 2008) at 3-4; M. Todd Parker, "The Freedom to Manifest Religious Belief: An Analysis of the Necessity Clauses of the ICCPR and the ECHR” (2006) 17 Duke J. Comp. \& Int'l L. at 91-92.

49 Peter Radan, "International Law and Religion: Article 18 of the International Covenant on Civil and Political Rights" in Peter Radan et al. eds., Law and Religion: God, the State and the Common Law (Routledge, 2005) at 17; Kyriakos N. Kyriazopoulos, "Proselytization in Greece: Criminal Offense vs. Religious Persuasion and Equality" (2004) 20 J.L. \& Religion at 168-179.

50 Li-ann Thio, “Constitutional 'Soft' Law and Management of Religious Liberty and Order: The 2003 Declaration on Religious Harmony” (2004) S.J.L.S. at 422.

51 Stephen C. Berkwitz, "Religious Conflict and the Politics of Conversion in Sri Lanka" in Rosalind I.J. Hackett ed., Proselytization Revisited: Rights Talk, Free Markets and Culture Wars (Equinox, 2008) at 216; Li-ann Thio, “Contentious Liberty: Regulating Religious Propagation in a Multi-Religious Secular Democracy” (2010) S.J.L.S. at 510.

52 Leonard A. Leo et al., "Protecting Religions from 'Defamation': A Threat to Universal Human Rights Standards” (2011) 34 Harv. J.L. \& Pub. Pol'y at 782; Daniel O. Conkle, "Religious Truth, Pluralism, and Secularization: The Shaking Foundations of American Religious Liberty" (2011) 32 Cardozo L. Rev. at 1757-1762; William P. Marshall, "Truth and Religion Clauses” (1994) 43 DePaul L. Rev. at 255-260 (advocating the search for truth as a justification of the Religion Clauses). 
for religious liberty is founded on the obligation of each person to pursue the truth about religious matters and to live in conformity with his conscientious judgments." 53 Rodney K. Smith and Patrick A. Shea noted that "[r]eligious liberty is also supported by the significant value that we accord to the pursuit of truth...There is a special role for religion in the pursuit of truth, a role worthy of protection." 54

The religious truth-seeking argument resembles the "marketplace of ideas" rationale supporting freedom of speech. The "marketplace of ideas" envisages that the best test of the truth of an idea is its acceptance in the context of free competition with opposing ideas. ${ }^{55}$ In the same vein, by allowing religion to "flourish according to the zeal of its adherents and the appeal of its dogma,"56 religious truth is more likely to emerge and to be accepted. ${ }^{57}$ As noted above, proselytisation restrictions prevent free competition for adherents among the different religions in a manner that is often discriminatory to minority religions. ${ }^{58}$ Such restrictions also entrench religious majorities through legal measures designed to prevent individuals from leaving the religious community rather than ensuring their continued adherence based on informed voluntary choice. ${ }^{59}$ Thus, proselytisation restrictions not only infringe the religious liberty of the propagators but also harm the common good of the religious truth-seeking process.

53 Robert P. George, “Natural Law” (2008) 31 Harv. J.L. \& Pub. Pol’y 171, 183-184.

54 Rodney K. Smith \& Patrick A. Shea, "Religion and the Press: Keeping First Amendment Values in Balance” (2002) 2002 Utah L. Rev. 177, 200.

55 Geoffrey R. Stone et al., Constitutional Law, 5th ed. (Aspen Publishers, 2005) at 1054-1056; William P. Marshall, "Truth and Religion Clauses" (1994) 43 DePaul L. Rev. at 256; Lawrence Rosenthal, "First Amendment Investigations and the Inescapable Pragmatism of the Common Law of Free Speech" (2011) 86 Ind. L.J. at 61-62 \& 61 n.288; Steven G. Gey, "The First Amendment and the Dissemination of Socially Worthless Untruths" (2008) 36 Fla. St. U.L. Rev. at 6-9.

56 Zorach v. Clauson 343 U.S. 306, 313 (1952).

57 William P. Marshall, "Truth and Religion Clauses” (1994) 43 DePaul L. Rev. at 255-256; M.H. Ogilvie, "Between Liberté and Égalité: Religion and the State in Canada" in Peter Radan et al. eds., Law and Religion: God, the State and the Common Law (Routledge, 2005) at 154.

58 Supra II.A.

59 Li-ann Thio, “Contentious Liberty: Regulating Religious Propagation in a Multi-Religious Secular Democracy” (2010) S.J.L.S. at 492. 


\section{Restrictions on religious propagation in Singapore}

Perhaps unsurprisingly, given the international image of Singapore as an illiberal authoritarian state where civil liberties are frequently curtailed, ${ }^{60}$ religious propagation is subjected to restrictions in Singapore. This Part examines Singapore's legal regime on religious propagation, noting the social backdrop of a diverse religious landscape, the myriad arsenal of laws affecting religious speech, and the application of these legal tools on recent incidents involving offensive religious propagation.

\section{A. Diverse Religious Landscape}

Singapore's religious landscape reflects its British colonial history as an immigrant-populated trading port. ${ }^{61}$ As Indian and Arab traders, European colonialists, and Indian and Chinese migrants arrived in Singapore, they brought with them the religious practices of their respective home countries. ${ }^{62}$ This resulted not only in a multi-ethnic society but also one teeming with vibrant religious diversity. According to the recently completed 2010 census, the Chinese constitute the majority (74.1\%) of the resident population, with Malays (13.4\%) and Indians (9.2\%) as the other two significant minority racial communities. ${ }^{63}$ An aggregation of other ethnic groups, such as Peranakans, Eurasians, ${ }^{64}$ Arabs, Armenians, and Jews, constitute the remaining 3.3\%. The religious composition of the population is even more diverse, notwithstanding the failure of the official religious categorisation to capture the large internal variations within the

60 E.g., Stephan Ortmann, Politics and Change in Singapore and Hong Kong: Containing Contention (Routledge, 2010) at 73-75 \& 126-127; William Case, Politics in Southeast Asia: Democracy or Less (Curzon, 2002) at 90-95.

61 See generally Jaime Koh \& Stephanie Ho, Culture and Customs of Singapore and Malaysia (Greenwood Press, 2009) at 1-24 (a concise historical account of the region).

62 Ibid., at 27-40; Eugene K. B. Tan, "Keeping God in Place: The Management of Religion in Singapore" in Lai Ah Eng ed., Religious Diversity in Singapore (Institute of Southeast Asian Studies, 2008) at 55, 56.

63 Singapore Department of Statistics, Census of Population 2010 Statistical Release 1: Demographic Characteristics, Education, Language and Religion (2011) at viii.

64 The ancestry of Peranakans and Eurasians can be traced back to the fifteenth-century Malacca Sultanate. Peranakans are descendents of Chinese traders and local Malay women, while Eurasians are the direct offspring of Malacca's Portuguese conquerors who married local women: Jaime Koh \& Stephanie Ho, Culture and Customs of Singapore and Malaysia (Greenwood Press, 2009) at 3-4. For census purpose, the ethnicity is as declared by the individuals and does not necessarily reflect the historical ancestry. 
following official categories. ${ }^{65}$ Buddhism is the most populous religion, at $33.3 \%$, followed by Christianity (18.3\%), Islam (14.7\%), Taoism (10.9\%), Hinduism (5.1\%), and other religions $(0.7 \%)$, with $17.0 \%$ reporting no religious affiliation. ${ }^{66}$

A feature of Singapore's religious landscape is the significant correlation between religion and ethnicity: $97.7 \%$ of Buddhists and $99.8 \%$ of Taoists are Chinese, whereas $99.0 \%$ of Hindus are Indians. Christians and Muslims are more ethnically diverse. Muslims include Malays (83.5\%), Indians (12.6\%), Others (2.09\%), and Chinese (1.8\%), whereas Christians include Chinese (83.0\%), Others (10.5\%), Indians (5.98\%), and Malays (0.47\%). Almost all Malays are Muslims. ${ }^{67}$ This close correlation between religion and ethnicity renders religious issues particularly sensitive. ${ }^{68}$ Singapore experienced incidents of communal violence in the mid-twentieth century that often reflected a volatile combination of religious and racial undertones. ${ }^{69}$

65 Kuah-Pearce Khun Eng, State, Society and Religious Engineering: Towards a Reformist Buddhism in Singapore (Eastern Universities Press, 2003) at 136.

66 Singapore Department of Statistics, Census of Population 2010 Statistical Release 1: Demographic Characteristics, Education, Language and Religion (2011) at 13.

67 Ibid., at 156.

68 Chee Kiong Tong, Rationalizing Religion: Religious Conversion, Revivalism, and Competition in Singapore Society (Koninklijke Brill, 2007) at 235; Li-ann Thio, "Control, Co-optation and Cooperation: Managing Religious Harmony in Singapore's Multi-ethnic, Quasi-Secular State" (2006) 33 Hastings Const. L.Q. 197, 234. U.S. style culture war in the Singapore context could also be even more divisive with the potential faults lines drawn between different religions or ethnic groups: Clarissa Oon, "Singapore v Taiwan: Seeking an active citizenry - without the fist fights” The Straits Times (20 September 2008).

69 For example, the Maria Hertogh court case in 1950 sparked riots by Muslims against Christians, especially the Europeans and Eurasians. Maria Hertogh was a Dutch-Eurasian who was baptized as a Catholic but was later raised as a Muslim by a Muslim family after her parents was arrested by the Japanese during the Second World War. She went through a marriage ceremony with a Muslim but the court annulled the marriage and sent her to a Catholic convent. Given the colonial context, it is not surprising that the Malay Muslim population perceived the court judgment as imposing of European cultural, racial and religious supremacy: see Chee Kiong Tong, Rationalizing Religion: Religious Conversion, Revivalism, and Competition in Singapore Society (Koninklijke Brill, 2007) at 232; Kuah-Pearce Khun Eng, State, Society and Religious Engineering: Towards a Reformist Buddhism in Singapore (Eastern Universities Press, 2003) at 142-143. The Malay-Chinese riots in the 1964 similarly reflected the inextricable nature of race and religion in Singapore's socio-political dynamics. Racial tension was already strained over whether Malays should be granted special rights as indigenous people, but the flash point was alleged the religious insults during the Muslim's possession in celebration of the Prophet Mohammed birthday: Chee Kiong Tong, Rationalizing Religion: Religious Conversion, Revivalism, and Competition in Singapore Society (Koninklijke Brill, 2007) at 232-233; Tey Tsun Hang, "Excluding Religion from Politics and Enforcing Religious Harmony - Singapore-Style" (2008) 2008 S.J.L.S. 118, 121; Kuah-Pearce Khun Eng, State, Society and Religious Engineering: Towards a Reformist Buddhism in Singapore (Eastern Universities Press, 2003) at 143. 
The diversity of Singapore's religious landscape is matched by its fluidity. Religious switching is increasingly common in Singapore. In a 2008 survey, 20\% of adults "abandon[ed] the religion they were born into before age 30," compared to $11.5 \%$ in $1990 .^{70}$ In 30 years, ${ }^{71}$ Buddhism saw its proportion of the population increase from $26.7 \%$ in the 1980 census to a high of $42.5 \%$ in 2000 before receding to the current $33.3 \%$. Taoism experienced a steady decline from $29.3 \%$ in 1980 to a low of $8.5 \%$ before bouncing back to $10.9 \%$ in $2010 .^{72}$ It is important to note that the distinction between Buddhism, Taoism, and traditional Chinese folk religions is often difficult to make. ${ }^{73}$ The fluctuations in the proportions of Buddhism and Taoism often involve reclassification between the two religions. ${ }^{74}$

The fluctuations in the populations of Buddhism and Taoism underlie a general and steady decline of these two religions, from 56\% in 1980 to $44.2 \%$ in 2010. This corresponds with the gains of Christianity and those who profess no religious affiliation. The Christian population has experienced consistent growth, from $10.1 \%$ in 1980 to $18.3 \%$ in 2010. This echoes a 2008 survey that found that although only $5.7 \%$ of youth switched religions, most conversions were from Buddhism or Taoism to Christianity. ${ }^{75}$ People who professed no religious affiliation also increased from $13.0 \%$ in 1980 to $17.0 \%$ in 2010 .

The religious composition of Malays and Indians has remained fairly stable over the time period. ${ }^{76}$ Most religious conversions and switching are concentrated in the Chinese population. ${ }^{77}$ Christianity, with its growth of rate of $25 \%$

70 Arti Mulchand, "Religion: The big switch" The Straits Times (9 August 2008).

71 Pre-independence population census by the Colonial government had included religious affiliation till 1931, when the persistent close correlation between race and religion render enquires of little value. Collection on religious affiliation data was only resumed in 1980: Chee Kiong Tong, Rationalizing Religion: Religious Conversion, Revivalism, and Competition in Singapore Society (Koninklijke Brill, 2007) at 58-59.

72 Singapore Department of Statistics, Census of Population 2010 Statistical Release 1: Demographic Characteristics, Education, Language and Religion (2011) at 13.

73 Jaime Koh \& Stephanie Ho, Culture and Customs of Singapore and Malaysia (Greenwood Press, 2009) at 32; Joseph B. Tamney \& Riaz Hassan, Religious Switching in Singapore: A Study of Religious Mobility (Select Books, 1987) at 6.

74 Richard Lim, “Buddhism's Draw is No Longer as a Folk Religion” The Straits Times (20 May 20 2005); Chee Kiong Tong, Rationalizing Religion: Religious Conversion, Revivalism, and Competition in Singapore Society (Koninklijke Brill, 2007) at 89.

75 "Four in Five Young People Here Believe in Religion" The Straits Times (3 September 2008). 76 Singapore Department of Statistics, Census of Population 2010 Statistical Release 1: Demographic Characteristics, Education, Language and Religion (2011) at 14.

77 Li Xueying, "Reaping a rich harvest of converts" The Straits Times (16 July 2005); Phyllis Ghim-Lian Chew, "Religious Switching and Knowledge Among Adolescents in Singapore” in Lai Ah Eng ed., Religious Diversity in Singapore (Institute of Southeast Asian Studies, 2008) at 381, 388-390. 
per decade, has replaced Taoism as the second most important religion of the Chinese, but Christianity has not gained ground among Malay and Indians. ${ }^{78}$ Indeed, a significant number of Christian Indians have already converted to Christianity in India prior to migrating to Singapore. ${ }^{79}$ One reason for this phenomenon is that religion is not tied to the Chinese ethnicity. In contrast, conversion away from Islam and Hinduism is low due to the "close interrelationship between religion, ethnicity and the sense of community in these two religions, and conversion is often seen as giving up on their cultures."80

\section{B. Legal Framework}

\section{Religious Liberty in the Constitution}

As in most Constitutions enacted after the Second World War, Singapore's Constitution enshrined the guarantee of religious freedom. Article 15(1) provides, "[e]very person has the right to profess and practice his religion and to propagate it." However, like most other constitutional guarantees in Singapore's Constitution, Article 15 is qualified by "any general law relating to public order, public health or morality." 81 Article 16(2) further provides for "the right to establish and maintain institutions for the education of children and provide therein instruction in its own religion." In addition, Article 16(3) states, "[n]o person shall be required to receive instruction in or to take part in any ceremony or act of worship of a religion other than his own." Interestingly, Article 16 is one of the few constitutional provisions that does not have a limitation clause.

Article 15(3) further protects the autonomy of religious organisations: "Every religious group has the right (a) to manage its own religious affairs; (b) to establish and maintain institutions for religious or charitable purposes; and (c) to acquire and own property and hold and administer it in accordance with law." Religious institutional autonomy is further strengthened by Article 12(3) (b). Article 12 is the equal protection clause of Singapore's Constitution, which

78 Leow Bee Geok, Census of Population 2000: Advance Data Release (2001) at 35; Chee Kiong Tong, Rationalizing Religion: Religious Conversion, Revivalism, and Competition in Singapore Society (Koninklijke Brill, 2007) at 60-62.

79 Chee Kiong Tong, Rationalizing Religion: Religious Conversion, Revivalism, and Competition in Singapore Society (Koninklijke Brill, 2007) at 62. Also, 97.1\% of Indians were "born into their religion": Ibid., at 84 .

80 Chee Kiong Tong, Rationalizing Religion: Religious Conversion, Revivalism, and Competition in Singapore Society (Koninklijke Brill, 2007) at 81.

81 Constitution of the Republic of Singapore (1999 Rev. Ed.), art. 15(4). 
prohibits religious discrimination. However, Article 12(3)(b) expressly permits religious institutions to exclude non-adherents from "office or employment connected with the affairs of any religion, or of an institution managed by a group professing any religion."

There is no general prohibition against the establishment of religion under Singapore's Constitution. Nonetheless, there are certain provisions that indirectly address issues that are commonly associated with the establishment clause. For example, Article 15(2) prevents the imposition of taxes "which are specially allocated in whole or in part for the purposes of a religion other than his own." Government support for minority religions appears to be constitutionally prescribed under Article 152(1), which renders the government responsible "to care for the interests of the racial and religious minorities in Singapore." Article 153 also authorises the government to make laws regulating Muslim religious affairs.

\section{Legal Arsenal Against Offensive Proselytisation}

Proselytisation has always been a sensitive issue in the diverse religious landscape of Singapore. Aggressive and insensitive proselytisation has been perceived by the government as a threat to religious harmony. ${ }^{82}$ In response, there is a wide array of legal tools available for the sanctioning of offensive religious propagation.

\section{a) Maintenance of Religious Harmony Act}

The Maintenance of Religious Harmony Act ("MRHA") is legislation enacted in 1990 that grants broad discretionary power to the executive branch to issue restraining orders against any officials or leaders of religious groups for conduct that may threaten religious harmony. The first ground for the issuance of the restraining order is "causing feelings of enmity, hatred, ill-will or hostility between different religious groups." ${ }^{83}$ Notably, intention as a relevant factor is eliminated under the legislative scheme. The Minister is entrusted with preempting actions that have the potential to upset religious harmony, even if

82 Daryl Chin, "Ex-foes link up to promote religious tolerance” The Straits Times (21 November 2010); Zakir Hussain, "Religious harmony: 20 years of keeping the peace” The Straits Times (24 July 2009) (noting various government pronouncement about aggressive proselytisation).

83 Maintenance of Religious Harmony Act (Cap. 167A), s. 8. 
these actions are undertaken with the best intentions. ${ }^{84}$ The restraining order is backed by imprisonment up to a maximum of two years for the first offence and three years for a repeated offence. ${ }^{85}$ Judicial review is expressly excluded, with the discretion of the Minister only partially checked by the requirement for confirmation by the Elected President acting on the advice of the Presidential Council of Religious Harmony. ${ }^{86}$

The key motivation of the clause is that aggressive proselytisation, especially proselytisation that includes offensive speech disparaging other religions, will upset the targeted religious adherents. ${ }^{87}$ The White Paper leading to the MHRA expressly noted that "while every citizen is free to choose his own religion...no citizen [should] infringe upon the rights and sensitivities of other citizens." 88

To date, no restraining order has been issued pursuant to the MHRA. Nonetheless, in 2001, the government discussed three examples for which the MHRA was almost invoked. Two of the three examples involved offensive religious speech. The first case involved a Christian pastor who had criticised Buddhism, Taoism, and Catholicism in his church publications and during his sermons. ${ }^{89}$ The second case involved an Islamic religious leader who claimed that a Hindu belief that statues of Ganesha could drink milk offerings was not a miracle but the work of Satan. ${ }^{90}$ A government warning under the shadow of the $M H R A$ was sufficient to stop these speeches.

84 Jothie Rajah, "Policing Religion: Discursive Excursions into Singapore's Maintenance of Religious Harmony Act” in Penelope (Pip) Nicholson \& Sarah Biddulph eds., Examining Practice, Interrogating Theory: Comparative Legal Studies in Asia (Martinus Nijhoff, 2009) at 267, 276-277.

85 Maintenance of Religious Harmony Act (Cap. 167A) at s. 16.

86 Ibid., at ss. 12 \&18. The Elected President is an position set up in 1991 to serve as institutional check on the parliamentary executive over various public finance and public administration matters. The Elected President is elected in a national election and served a four-year term. The efficacy of the independent check provided by the Elected President is arguable given that the position has been occupied by individuals that are perceived as formerly affiliated or otherwise sympathetic to the ruling party: see Li-ann Thio, "Lex Rex or Rex Lex? Competing Conceptions of the Rule of Law in Singapore” (2002) 20 UCLA Pac. Basin L.J. 1, 15-22 \& 50-53. It is also worth pointing out that the this ouster clause has yet to be tested in courts.

87 Chee Kiong Tong, Rationalizing Religion: Religious Conversion, Revivalism, and Competition in Singapore Society (Koninklijke Brill, 2007) at 247; M. Nirmala, "Govt reins in religious leaders" The Straits Times (12 May 2001) at 1.

88 Maintenance of Religious Harmony White Paper (Cmd 21 of 1989), para. 5.

89 M. Nirmala, “Govt Reins in Religious Leaders” The Straits Times (12 May 2001).

90 Ibid.; Michael Hill, "The Rehabilitation and Regulation of Religion in Singapore" in James T. Richardson ed., Regulating Religion: Case Studies from Around the Globe (Kluwer Academic, 2004) at 343, 356. 
The restraining order under the $M H R A$ is essentially a pre-emptive tool that allows the government to intervene discreetly without a public criminal conviction. ${ }^{91}$ Notwithstanding the seeming lack of actual enforcement of the MHRA, the ramifications of the mere presence of the law are keenly felt by the various religious groups in Singapore. Religious leaders agreed that the law is an effective deterrent. ${ }^{92}$ The Hindu community, which had previously expressed grave concerns over aggressive proselytisation by Christians, felt that the law helped to curb this proselytisation and helped to maintain the proportion of Hindus at $4 \% .^{93}$ The Christian Church has attempted to adjust its evangelistic methods by adopting more "gentleness and respect" in light of the MHRA.94 Indeed, a booklet on the topic of inter-faith relationships, prepared by the National Church Council Singapore and distributed to its member churches, emphasised the power of available sanctions under the MHRA. ${ }^{95}$ Similarly, a pamphlet produced by a Buddhist organisation presented the MHRA as a possible legal remedy against insensitive proselytisation. ${ }^{96}$

\section{b) Sedition Act}

The Sedition Act is a legacy of colonial times. ${ }^{97}$ Originally meant to protect the political institution of the country, ${ }^{98}$ it has been employed in Singapore to sanction speech that offends religious and racial sensitivities. Under section 3(1)(e) of the Sedition Act, a tendency "to promote feelings of ill-will and hostility between different races or classes of the population of Singapore" would amount to a

91 Though the process is not secret. Section 15 requires the publication of the restraining order in the Government Gazette: Maintenance of Religious Harmony Act (Cap. 167A) at s. 15.

92 M. Nirmala, "Keeping faith - And celebrating differences” The Straits Times (12 May 2001) at H10.

93 Ibid.

94 Mathew Mathews, "Accommodating Relationship: The Church and State in Singapore” in Julius Bautista \& Francis Khek Gee Lim eds., Christianity and the State in Asia (Routledge, 2009) at 193 (although this could also be due to the perception that less aggressive evangelistic strategy is more successful in the long term).

95 Zhou Shuxin, "Ge zhongjiao tuanti linxiu: chuanjiao xu zhunzhong bieren zhongxiao xingyang [Various religious organisation leaders: Must respect others' religious belief during proselytization]" Lianhe Zaobao (11 February 2010).

96 Debbie Tan, “Agree to Disagree: Conversations on Conversion”, online: <www.conversion. buddhists.sg> (last visited 1 February 2013) at 18.

97 Jaclyn Ling-Chien Neo, "Seditious in Singapore! Free Speech and the Offence of Promoting Ill-Will and Hostility Between Different Racial Groups” (2011) S.J.L.S. at 353-355 (discussing the historical origin of the Sedition Act).

98 Ibid., at 354-355. 
seditious tendency that is punishable by a fine and a maximum of three years imprisonment. ${ }^{99}$ Significantly, the intention of the party is irrelevant. ${ }^{100}$

Until 2005, the last time the Sedition Act was employed was in the 1960s, when opposition Barisan Sosialis MPs were fined for "an article which accused the then People's Action Party government of plotting to murder a political detainee." ${ }^{101}$ In 2005, two Chinese men were charged under the Sedition Act for posting inflammatory racist and vicious remarks about Muslims and Malays online. ${ }^{102}$ They pleaded guilty and were sentenced to one month of imprisonment and one day of imprisonment. Koh Song Huat, who received the onemonth jail term, posted comments that "spewed vulgarities at the Muslim Malay community, derided and mocked their customs and beliefs and profaned their religion," according to the Public Prosecutor. ${ }^{103}$ The prosecution was conducted against the backdrop of an increase in online racist remarks in recent years. ${ }^{104}$

\section{c) New Penal Code Provision: Section 298A}

Singapore's Penal Code was amended in 2007 to include a new criminal offense of "promoting enmity between different groups on grounds of religion or race and doing acts prejudicial to maintenance of harmony."105 The addition was intended to include actions that were previously not covered by the existing offence of deliberately wounding the religious feelings of another. ${ }^{106}$ During parliamentary debate, the Senior Minister of State for Home Affairs (the proponent of the amendment bill) explained that the new section was not intended to include journalistic coverage of sensitive factual events or critical but "rational and objective discussion of religion and religious principles." He reiterated that "everyone has the right to hold his own religious beliefs and to accept or not to accept any religion."107 In this regard, sharing one's testimony of fulfillment

99 Sedition Act (Cap. 290), s. 4.

100 Ibid., at s. 3(3).

101 Lydia Lim, Zakir Hussain \& William Han, "Drawing the line on racist remarks" The Straits Times (24 September 2005); Jaclyn Ling-Chien Neo, "Seditious in Singapore! Free Speech and the Offence of Promoting Ill-Will and Hostility Between Different Racial Groups” (2011) S.J.L.S. at 356-357.

102 Chong Chee Kin, “Racist bloggers jailed” The Straits Times (8 October 2005).

103 Ibid. ("one comment compared the Muslim religion to Satanism").

104 Aaron Low, "Online or off, if it fans hatred, govt will act” The Straits Times (18 September 2005).

105 Penal Code (Cap. 224), s. 298A.

106 Penal Code (Amendment) Bill, Parliament No. 11 Hansard Vol. 15 (2007) (Ho Peng Kee); Penal Code (Cap. 224) at s. 298.

107 Penal Code (Amendment) Bill, Parliament No. 11 Hansard Vol. 15 (2007) (Ho Peng Kee). 
through conversion is allowed as long as it does not involve denigrating another person's religion. ${ }^{108}$

The bill received broad support from the MPs. ${ }^{109}$ One MP highlighted the "thin line between promoting religion and promoting enmity between different groups of people on grounds of religion" and noted that the "aggressive promotion of religion by any religious group will usually result in unhealthy competition, and tension among different religious groups, thus disrupting our national unity."110

\section{d) Internal Security Act}

The final and perhaps most potent tool in the government's arsenal is the infamous Internal Security Act. ${ }^{111}$ The Internal Security Act is a relatively lengthy piece of legislation spanning 84 different sections that address a myriad of issues, such as regulations for security areas and prohibitions on quasi-military organisations. However, section 8 defines the Internal Security Act in the public imagination. Section 8 of the Internal Security Act prescribes the power of the executive branch to order detention without trial for up to two years, with the additional power to extend the detention an infinite number of times. More significantly, judicial review of the detention order is restricted to procedural matters as expressly set forth under the Internal Security Act. ${ }^{112}$ Such extensive and discretionary power vested in the executive branch can create "almost irrational fear among the people."113 This is enhanced in the context of Singapore, where the overwhelming political dominance of the ruling party has been employed to amend the Constitution to limit the expansion of judicial review by the courts. ${ }^{114}$

108 Ibid. (Ho Peng Kee).

109 Ibid. (Zaqy Mohamad; Ong Kian Min; Muhammad Faishal Ibrahim; Charles Chong; Lim Biow Chuan).

110 Ibid. (Teo Ho Pin).

111 Internal Security Act (Cap. 143).

112 Ibid., at s. 8B. After the Court of Appeal (the highest court) held that an illegally, irrationally or procedurally improper exercise of government power would trigger judicial review even for the broadly defined discretion of detention powers under the Internal Security Act, the Constitution and the Internal Security Act were amended to revert the law to the doctrine prior to that decision: Gordon Silverstein, “Singapore: The Exception that Proves Rules Matter” in Tom Ginsburg \& Tamir Moustafa eds., Rule by Law: The Politics of Courts in Authoritarian Regimes (Cambridge University Press, 2008) at 73, 79-81; Li-ann Thio, "Lex Rex or Rex Lex? Competing Conceptions of the Rule of Law in Singapore” (2002) 20 UCLA Pac. Basin L.J. at 18, 58-63.

113 Farid Sufian Shuaib, "Controlling Political Communication in the Blogosphere: Business as Usual in Malaysia” (2011) 16(1) Comms. L. 27, 28-29 (discussing similar laws in Malaysia).

114 Supra note 112. 
The power of detention without trial was initially employed primarily against Communists and members of leftist political oppositions. ${ }^{115}$ However, religious leaders and individuals associated with religious organisations have also borne the brunt of the law in recent times. In 1986, 11 Christian leaders who had been evangelising to Muslims were called by the Internal Security Department and advised "to avoid activities which cause misunderstanding or conflict." "116 In 1987, 22 men and women associated with Catholic organisations, including four Catholic priests, were detained under the Internal Security Act for participating in "a Marxist conspiracy out to topple the Government by illegal means." "117 In the aftermath of the 2001 terrorist attacks in the United States, individuals professing radical Islamic beliefs have also been detained for plotting terrorist attacks in Singapore. ${ }^{118}$

\section{Regulating Offensive Proselytisation in Practice: Four Recent Incidents}

These various legal tools have been employed separately in a series of incidents over the short time span between 2009 and 2010.

\section{1. "Seditious" Comics: The Ong Kian Cheong Case}

The case of Public Prosecutor v. Ong Kian Cheong ("Ong Kian Cheong case")"119 involved the use of the Sedition Act. A couple who attended the Berean Christian

115 Kevin Y.L. Tan, “Constitutionalism in Times of Economic Strife: Developments in Singapore” (2009) 4 Nat'l Taiwan U.L. Rev. 115, 122; Tae Yul Nam, "Singapore’s One-Party System: Its Relationship to Democracy and Political Stability” (1969) 42(4) Pacific Affairs 465, 472-473.

116 Li-ann Thio, "Control, Co-optation and Co-operation: Managing Religious Harmony in Singapore’s Multi-ethnic, Quasi-Secular State” (2006) 33 Hastings Const. L.Q. at 240.

117 Lydia Lim \& Li Xueying, "The legacy of 1987" The Straits Times (7 July 2007); Chee Kiong Tong, Rationalizing Religion: Religious Conversion, Revivalism, and Competition in Singapore Society (Koninklijke Brill, 2007) at 239.

118 Between 2001 and 2002, 36 people were detained by the ISD under the Internal Security Act for alleged involvement in planning a radical Islamist terrorist attack on Singapore: Senia Febrica, "Securitizing Terrorism in Southeast Asia: Accounting for the Varying Responses of Singapore and Indonesia" (2010) 50(3) Asian Survey 569, 576-577. In February 2007, a law graduate was detained under the Internal Security Act for training for a militant jihad: Ken Kwek, "Learn about Islam from credible sources" The Straits Times (16 June 2007).

119 Public Prosecutor v. Ong Kian Cheong [2009] SGDC 163. 
Church at the time of the offences ${ }^{120}$ was charged with distributing certain evangelical comic tracts published by Chick Publications that were seditious and promoted feelings of ill-will between Christians and Muslims. ${ }^{121}$ Chick Publications is an American publishing company that produces "Protestant fundamentalist" materials. ${ }^{122}$ The couple was also charged with possession of other seditious publications, also by Chick Publications, which denigrated Islam, the Catholic Church, and other religious groups. ${ }^{123}$ The couple was arrested on 30 January 2008, when the police "laid an ambush" at the post box where the couple dropped off the materials. ${ }^{124}$ The Media Development Authority had previously informed the couple in November 2007 that two of the seven publications by Chick Publications that they had ordered were objectionable and had to be destroyed. ${ }^{125}$

The couple had been distributing religious pamphlets since 1987, switching from randomly stuffing the tracts in letter boxes to posting them to addresses taken from the phone directory. ${ }^{126}$ From 2000 until their arrest, 20,000 tracts were sent out. ${ }^{127}$ The couple deliberately sent the tracts critiquing Islam to persons with Muslim names. ${ }^{128}$ The tracts were sent anonymously. ${ }^{129}$

120 Elena Chong, "Couple admitted sending out tracts" The Straits Times (6 December 2008). 121 Public Prosecutor v. Ong Kian Cheong [2009] SGDC 163, at para. 4; Elena Chong, "Couple go on trial for sedition" The Straits Times (5 December 2008).

122 Elena Chong, “Couple go on trial for sedition” The Straits Times (5 December 2008).

123 Public Prosecutor v. Ong Kian Cheong [2009] SGDC 163, at paras. 4 \& 16.

124 Ibid., at para. 6; Elena Chong, "Couple go on trial for sedition" The Straits Times (5 December 2008).

125 Public Prosecutor v. Ong Kian Cheong [2009] SGDC 163, at paras. 17-19. This resulted in three visits by the couple to the MDA. In the third visit, the couple took home the tracts which were not found objectionable by MDA, though the couple denied being told why the tracts were detained. The wife also claimed that the husband "was not paying attention and occupied himself looking at the posters displayed in the office" when she was talking to the MDA officer: Ibid., at paras. 17-19. The couple had approached the case with a diminished role of the husband in the activities, i.e. involved only in the physical activity of posting: Ibid., at paras. $27,43 \& 61$.

126 Ibid., at paras. 25-27 \& 29-32; Elena Chong, "Accused says he had not read offensive comics” The Straits Times (30 January 2009). Direct mailing as a means of spreading the gospel messages has been an established strategy of Christian evangelicalism in Singapore: KuahPearce Khun Eng, State, Society and Religious Engineering: Towards a Reformist Buddhism in Singapore (Eastern Universities Press, 2003) at 279-280.

127 Elena Chong, “'20,000' tracts mailed over 7 years” The Straits Times (7 April 2009).

128 Public Prosecutor v. Ong Kian Cheong [2009] SGDC 163, at para. 35.

129 The couple testified that they did not identify themselves as senders on the envelopes because they did not see the need to communicate at all with the tract recipients: Ibid., at paras. $26 \& 32$. The judge agreed with the public prosecutor that the anonymity was intended to avoid detection: Ibid., at paras. $73 \& 83$. 
The couple proclaimed that they only wanted to spread Christianity and apologised for any hurt feelings. ${ }^{130}$ One of the defenses offered by the accused was that the materials she distributed were not different from other publicly available materials, particularly the $\mathrm{Da}$ Vinci Code in book and film format. ${ }^{131}$ The prosecution expert witness, Mr. A.R. Madeei, the Media Development Authority's senior assistant director (publications), testified in court that there was a distinction between books such as God is Not Great, The End of Faith, The Da Vinci Code, and The God Delusion and a comic tract that was easily accessible and understood by the young and vulnerable. ${ }^{132}$ Another defense advanced by the couple was ignorance of the content of the tracts, ${ }^{133}$ especially with tracts being openly sold in bookstores in Singapore. ${ }^{134}$ These defenses were rejected, and the couple was convicted and jailed eight weeks. ${ }^{135}$

\section{2. "Injurious" Cards: the Andrew Kiong Case}

The new Penal Code Provision section 298A was employed once, in 2010. An airconditioning repairman, Andrew Kiong Kheng Kiat, was jailed for two weeks after he was convicted under section 298A for "injuring religious feelings of another person."136 During his work at several condominiums, he moved around the car parks leaving envelope-sized cards on the windshields of cars that he believed belonged to Muslim residents. ${ }^{137}$ The cards "contained questions about

130 Elena Chong, “Couple admitted sending out tracts” The Straits Times (6 December 2008).

131 Carolyn Quek, “Tracts 'no different from da vinci code”" The Straits Times (11 March 2009). 132 Public Prosecutor v. Ong Kian Cheong [2009] SGDC 163, at paras. 55-56; Elena Chong, "Booklets available in store, says lawyers" The Straits Times (29 January 2009).

133 Public Prosecutor v. Ong Kian Cheong [2009] SGDC 163, at paras. 28, 33; Elena Chong, "Accused says he had not read offensive comics" The Straits Times (30 January 2009). Section 6 (2) of the Sedition Act provides an affirmative defence of ignorance of publication's seditious tendency, if there was no "want of due care or caution."

134 Public Prosecutor v. Ong Kian Cheong [2009] SGDC 163, at para. 33 (The couple provided evidence by way of photographs taken in November 2008 of the tracts being sold at a local bookstore, although the judge noted that the couple had been ordering the tracts directly online from Chick Publications since 2000, and thus did not believed the couple's defence that the offensive tracts were purchased at the local bookstore.).

135 Public Prosecutor v. Ong Kian Cheong [2009] SGDC 163, at paras. 44-66, 86; Carolyn Quek, "Seditious tract duo jailed eight weeks" The Straits Times (11 June 2009).

136 Khushwant Singh, "Jailed for 'wounding feelings' of Muslims” The Straits Times (7 August 2010).

137 Ibid. 
the Prophet Muhammad that were calculated to insult Muslims."138 The Muslim owners of the cars consulted the Islamic Religious Council of Singapore (Muis), a statutory board in charge of Muslim affairs, ${ }^{139}$ before lodging the police report that led to the arrest. ${ }^{140}$ Compared to the Ong Kian Cheong case, this case received much less media publicity in the mainstream press. Academic discussion on the case was also scant. ${ }^{141}$

\section{3. “Unacceptable” Testimonials: The Pastor Tan Incident}

In February 2010, Senior Pastor Rony Tan, founder of the Lighthouse Evangelism Church, was called up by the Internal Security Department over three video clips posted on the church website. ${ }^{142}$ The three clips involved testimonials of people who converted to Christianity from other religions. The first two video clips showed Pastor Tan interviewing a former Buddhist monk regarding his frustration about chanting words he did not understand and not receiving straight answers from Buddhist elders about attaining nirvana. "Pastor Tan drew laughter from his audience with his remarks on the chanting, and compared [the former Buddhist monk's] effort to seek answers from his mentors as 'the blind leading the blind." ${ }^{143}$ In the third clip, Pastor Tan suggested that the meditation experience of another former Buddhist was the work of a "demon."144 Pastor Tan also critiqued the Buddhist precepts of rebirth, karma, and nirvana. ${ }^{145}$

According to the official statement by the Home Affairs Ministry that confirmed that the "called up," "Pastor Tan's comments were highly inappropriate and unacceptable as they trivialised and insulted the beliefs of Buddhists and

138 Ibid.

139 See Ahmad Nizam Bin Abbas, "The Islamic Legal System in Singapore” (2012) 21 Pac. Rim L. \& Pol'y J. 163, 167-171 (discussing the function and structure of MUIS).

140 Khushwant Singh, “Jailed for 'wounding feelings' of Muslims” The Straits Times (7 August 2010).

141 The case was mentioned in passing in Jaclyn Ling-Chien Neo, "Seditious in Singapore! Free Speech and the Offence of Promoting Ill-Will and Hostility Between Different Racial Groups" (2011) S.J.L.S. at 363.

142 Yen Feng, "ISD calls up pastor for insensitive comments" The Straits Times (9 February 2010). For a background of Pastor Rony Tan, see Jennani Durai, "The man behind the controversy" The Straits Times (9 February 2010).

143 Yen Feng, "ISD calls up pastor for insensitive comments" The Straits Times (9 February 2010).

144 Ibid.

145 Ibid. 
Taoists."146 Pastor Tan was "told" by the ISD that "in preaching or proselytizing his faith, he must not run down other religions, and must be mindful of the sensitivities of other religions."147 The Deputy Prime Minister, Wong Kan Seng, publicly noted that the ISD warning was no less serious than a police investigation. ${ }^{148}$

The matter was resolved after Pastor Tan's various apologies. First, he removed the video and posted an apology on the website. ${ }^{149}$ The government statement noted, "Pastor Tan has expressed his deepest apologies and remorse" during the ISD "call up." 150 The Buddhist and Taoist leaders were initially indifferent to the apology and emphasised the need to prevent future incidents. ${ }^{151}$ Pastor Tan paid a personal visit the next day to the Buddhist and Taoist religious leaders to apologise. This led to reconciliation with the Buddhist and Taoist leaders, who appreciated the sincerity of Pastor Tan's apology. ${ }^{152}$ This was followed by an apology to his church members and an appeal to them not to defend or justify his actions to others. ${ }^{153}$ All of these actions led Deputy Prime Minister and Minister for Home Affairs Wong Kan Seng to tell the press that the religious leaders had led and set the right example. $^{154}$

146 "ISD Acts" The Straits Times (9 February 2010).

147 Ibid.

148 Chua Hian Hou, “Racist facebook postings: Three youths won't be charged” The Straits Times (13 February 2010).

149 "Pastor's Apology” The Straits Times (9 February 2010).

150 "ISD Acts" The Straits Times (9 February 2010).

151 Grace Chua, "Leaders of buddhist, taoist groups urge restraint" The Straits Times (9 February 2010) (Singapore Buddhist Federation' secretary-general, Venerable Kwang Phing: "It is good that the authorities have looked at this matter, but this is a matter of national concern. We want to appeal to the public and the authorities to make sure there is no second time"; Singapore Taoist Federation chairman Tan Thiam Lye: "If (Pastor Tan) is sincere, we accept his apology, and hope this sort of thing does not happen again.”). See also Yang Zhengjiang, "Mushi daoxian xianlan bugou chengyi [Apology by pastor is clearly not sufficiently sincere]" Lianhe Zaobao (13 February 2010) (a member of the public writing to the Chinese press opining that the online apology is not sufficiently sincere).

152 Yen Feng, "Buddhist, Taoist leaders accept pastor's apology” The Straits Times (10 February 2010).

153 Yen Feng, "Pastor: I’ve let many people down” The Straits Times (16 February 2010).

154 Yen Feng, "Buddhist, Taoist leaders accept pastor's apology" The Straits Times (10 February 2010). 


\section{4. “Looked Into" Sermons: the Pastor Ng Incident}

A similar incident occurred a few months after the Pastor Tan incident. In June 2010, the ISD was in action again, this time involving a video sermon by Pastor Mark Ng of New Creation Church, an independent church with 20,000 members. ${ }^{155}$ In the video, he "can be heard joking with the congregation about Chinese rituals; in one instance, he compared praying to Taoist deities to 'seeking protection from secret society gangsters.",156 Although the video was posted online by others, the ISD nevertheless "looked into it and [took] up the matter with the New Creation Church."157

The manner of resolution was similar to the Pastor Tan incident. The New Creation Church took steps to remove the sermon in question and to prevent distribution/reproduction. An initial apology was posted online on its website. ${ }^{158}$ Similar to the Pastor Tan incident, this initial apology was deemed inadequate by the offended parties. The Taoist Federations responded that "[m]any Taoists neither use the Internet nor speak English...It is not good enough that someone can make fun of our faith, and then just write an apology on the Internet."159

Similar to Pastor Tan, in response, Pastor Ng issued a statement to the press seeking forgiveness for his "serious indiscretion," 160 which was followed by a personal visit to the Taoist Federation chairman at his office to apologise. ${ }^{161}$ The Taoist Federation chairman, Tan Thiam Lye, accepted the apology, noting that the matter is now completely over and that both of them had become friends. ${ }^{162}$ Later that year, at a gathering celebrating the Taoist Federation's 20th Anniversary, Mr. Kang from the New Creation Church and Tam Thiam Lye sang a duet, the Hokkien ditty of love and kinship "Jit Lang Jit Puah," or "One Half for Each [Friend].”163 A picture perfect happy ending.

155 Yen Feng, "ISD looks into clip of sermon which mocked Taoist beliefs" The Straits Times (15 June 2010).

156 Ibid.

157 Ibid. (statement by the Ministry of Home Affairs).

158 Ibid.

159 Yen Feng, “New creation pastor apologises for 'indiscretion”" The Straits Times (16 June 2010).

160 Ibid.

161 Yen Feng, "Pastor says sorry and gains a friend" The Straits Times (17 June 2010).

162 Ibid.

163 Yen Feng, "Different faiths to gather at Taoist festivity" The Straits Times (1 December 2010). 


\section{ANalysis: feAtures of SINGAPORE'S RESTRICTIONS ON RELIGIOUS PROPAGATION}

Although the restrictions and their application to recent incidents have been subjected to significant commentary by local academics, ${ }^{164}$ this Part adds to the discourse by identifying several nuances and features of Singapore's regime that have been otherwise overlooked. In particular, this Part discusses the breath of the restrictions, the constitutional issue of "religious propagation," and the State's involvement in religious reconciliation.

\section{A. Beyond Offensive Proselytisation: The Breadth of Singapore's Restrictions}

Proselytisation has always been a sensitive issue in the diverse religious landscape of Singapore. Aggressive proselytisation has been perceived by the government as a threat to religious harmony ${ }^{165}$ given the appreciation that "no religion will idly stand by while its members are drawn away." ${ }^{166}$ In particular, "the government has always been alert to Muslim sensitivities towards Christian evangelism," 167 especially in the context of being surrounded by Muslim majority countries and where Islam is a focal point for Malay nationalism. ${ }^{168}$ The government has taken care to emphasise that it is not against religious

164 E.g., Jaclyn Ling-Chien Neo, "Seditious in Singapore! Free Speech and the Offence of Promoting Ill-Will and Hostility Between Different Racial Groups” (2011) S.J.L.S.; Li-ann Thio, "Contentious Liberty: Regulating Religious Propagation in a Multi-Religious Secular Democracy” (2010) S.J.L.S; Zhong Zewei, "Racial and Religious Hate Speech in Singapore: Management, Democracy, and the Victim's Perspective” (2009) 27 Sing. L. Rev.

165 Daryl Chin, "Ex-foes link up to promote religious tolerance” The Straits Times (21 November 2010); Zakir Hussain, "Religious harmony: 20 years of keeping the peace” The Straits Times (24 July 2009).

166 Chee Kiong Tong, Rationalizing Religion: Religious Conversion, Revivalism, and Competition in Singapore Society (Koninklijke Brill, 2007) at 267.

167 Li-ann Thio, "Control, Co-optation and Co-operation: Managing Religious Harmony in Singapore's Multi-ethnic, Quasi-Secular State” (2006) 33 Hastings Const. L.Q. at 238; Jean DeBernardi, “Asia's Antioch: Prayer and Proselytism in Singapore” in Rosalind I.J. Hackett ed., Proselytization Revisited: Rights Talk, Free Markets and Culture Wars (Equinox, 2008) at 258. 168 Jean DeBernardi, “Asia's Antioch: Prayer and Proselytism in Singapore” in Rosalind I.J. Hackett ed., Proselytization Revisited: Rights Talk, Free Markets and Culture Wars (Equinox, 2008) at 259-260; Li-ann Thio, "Control, Co-optation and Co-operation: Managing Religious Harmony in Singapore's Multi-ethnic, Quasi-Secular State” (2006) 33 Hastings Const. L.Q. at 238 . 
competition (obtaining more followers) per se but that sensitivity is required in Singapore's multi-racial and multi-religious setting. ${ }^{169}$ Indeed, "the government has urged that [proselytisation] must be exercised sensitively, by drawing a distinction between interested persons and attempts to convert people out of their faith by denigrating his religion, which could cause great offense."170 During the parliamentary debate on the new Penal Code provision, the Senior Minister of State for Home Affairs observed that "[i]t is one thing to preach to a person who is interested to hear your views. However, it is quite another to try to convert a person to your religion by denigrating his religion, especially when he has no desire to be converted."171

The recent incidents reflect the conventional attitude of Singapore's government toward insensitive proselytisation. In essence, religious propagation in Singapore is restricted by the rule that it should not "run down" other religions and must be mindful of other religions' sensitivities. This is beyond the concept of religious hate speech, where some type of incitement of discrimination, hostility, or violence is usually required. ${ }^{172}$ In terms of content, Pastor Tan's critique of Buddhism and Taoism may be flippant in tone, but there is no suggestion of demonising or ostracising the Buddhist and Taoist communities. Similarly, although the Chick Publication comic tracts were highly critical of Islam and certainly did not depict Muslim characters in a flattering light, they are still arguably within the boundaries of reasoned discourse. The inability to directly access the materials in the Pastor $\mathrm{Ng}$ incident and the Andrew Kiong case prevented direct commentary on the content in this Article, although there is nothing in the reported press to suggest greater severity of these offences in terms of tone or content.

Although the concept of "offensive" as the basis for sanctions has been given a broad and arguably crude definition, it is worth noting an interesting factual nuance that has been missed by most commentary and reports on the Ong Kian Cheong case that shed important light on the types of restrictions at

169 "Foolhardy to Take Harmony for Granted" The Straits Times (25 July2009) (Senior Minister and Coordinating Minister for National Security S. Jayakumar).

170 Li-ann Thio, "Control, Co-optation and Co-operation: Managing Religious Harmony in Singapore’s Multi-ethnic, Quasi-Secular State” (2006) 33 Hastings Const. L.Q. at 237.

171 Penal Code (Amendment) Bill, Parliament No. 11 Hansard Vol. 15 (2007) (Ho Peng Kee).

172 Anat Scolnicov, The Right to Religious Freedom in International Law (Routledge, 2011) at 206-207; Kathleen Mahoney, "Hate Speech, Equality, and the State of Canadian Law" (2009) 44 Wake Forest L. Rev. 321, 325-326. See also Brett A. Barnett, Untangling the Web of Hate: Are Online "Hate Sites" Deserving of First Amendment Protection? (Cambria Press, 2007) at 134 (observing that religious speech was "a major component of the vast majority of the sampled hate sites.”). 
hand. The publication the couple was caught mailing, another Chick Publications tract titled "Set Free," was actually not listed as a seditious publication in the charges. ${ }^{173}$ The couple had deliberately sent that particular tract to addresses with Chinese names. ${ }^{174}$ The tract contained the typical evangelical message of the other Chick Publications tracts (sinners going to hell, Jesus Christ dying for humans' sins, faith in Jesus Christ as the only path of salvation) but did not explicitly mention any other religion. ${ }^{175}$ This confirms that it is not religious propagation per se but only a particular form of religious propagation involving criticisms of other religions that is legally sanctioned.

However, the Pastor Tan and Pastor Ng incidents represent more than restrictions on insensitive proselytisation. Although Pastor Tan and Pastor Ng were not ultimately subject to legal punishments, the publicly announced callup by ISD constitutes a strong rebuke by the government. Their behavior was deemed "unacceptable," necessitating public apologies that were to be accepted by the offended parties. ${ }^{176}$ Close examination of the conduct of Pastor Tan and Pastor Ng reveals important distinctions from the insensitive proselytisation that was punished in the Ong Kian Cheong case and the Andrew Kiong case.

First, the "offensive" religious speeches by Pastor Tan and Pastor Ng were made to their own respective congregations. Although Pastor Tan uploaded a video containing the relevant religious speeches onto the internet, this was done through the church's own website and not through a public file-sharing medium. The video by Pastor Ng, which was distributed by the church in the form of compact discs, ${ }^{177}$ was actually uploaded by third parties intending to bring the issue to light. This is unlike the two criminal cases in which the propagators specifically intended the religious materials criticising Islam to be received by Muslims.

Second, the venues of the religious speeches were their respective places of worship. There was no unsolicited intrusion on the personal sphere of the offended parties, unlike in the two criminal cases, where the religious materials

173 Public Prosecutor v. Ong Kian Cheong [2009] SGDC 163, at para. 6.

174 Ibid., at para. 35.

175 Jack T. Chick, Set Free (Chick Publications, 2007), online: <http://www.chick.com/reading/ tracts/1037/1037_01.asp> (last visited 1 February 2013).

176 Supra III.C.3 \& III.C.4.

177 Yen Feng, "ISD looks into clip of sermon which mocked Taoist beliefs" The Straits Times (15 June 2010). The church reported that the church "stop reproducing" the particular sermons after the church reviewed their archive for insensitive materials after the Pastor Tan incident (February 2010), although the third party who uploaded the clip told the press that he received the materials from a Christian whom he presumed is the adherent of the New Creation church in May 2010: Ibid. 
were placed either on private property (the Andrew Kiong case) or in personally addressed parcels (the Ong Kian Cheong case). These cases also do not involve the more troubling practice of proselytising in "public institutions such as governments, schools, hospitals or offices."178

It appears that the "don't run others down" principle has been applied in Singapore to extend beyond mere proselytising. Such "insensitive" criticisms, even if they are only meant for consumption by one's congregation, are liable to result in sanctions and rebuke whenever they come to public awareness.

\section{B. Religious Propagation as a Constitutional Right}

The Singapore incidents involve a particular constitutional issue beyond the usual considerations of religious liberty. Prominent local constitutional scholar Li-ann Thio criticised the court in the Ong Kian Cheong case for side-stepping the general constitutional question of religious liberty and the importance of the expressly stipulated constitutional right to religious propagation. ${ }^{179}$ Indeed, she emphasised the specific inclusion of "propagation" in the Singapore Constitution as a distinguishing characteristic vis-à-vis other constitutional or human rights religious freedom formulations. ${ }^{180}$ She argued that the significance of the Singapore Constitution's inclusion of the express right to religious propagation is enhanced by the fact that restrictions against religious propagation among Muslim adherents were deliberately omitted from Singapore's Constitution. ${ }^{181}$

However, it is possible to attach excessive significance to the particularity of Singapore's constitutional wording. Li-ann Thio acknowledged that the right to "propagation" is "included in the Constitutions of some former British colonies in Asia (Singapore, Malaysia, India, Bangladesh, Pakistan), Africa (Botswana) and the Caribbean (St Lucia, Jamaica)."182 This suggests path dependency based on British colonial influence rather than a genuine bottom-up or otherwise local

178 Li Xueying \& Ken Kwek, “Say Aaah...men” The Straits Times (15 October 2005).

179 Li-ann Thio, “Contentious Liberty: Regulating Religious Propagation in a Multi-Religious Secular Democracy” (2010) S.J.L.S at 506-508.

180 Ibid., at 485-486; Li-ann Thio, "Constitutional 'Soft' Law and Management of Religious Liberty and Order: The 2003 Declaration on Religious Harmony” (2004) S.J.L.S. at 422.

181 Li-ann Thio, "Contentious Liberty: Regulating Religious Propagation in a Multi-Religious Secular Democracy” (2010) S.J.L.S. at 485-488.

182 Ibid., at 485. 
decision to incorporate such a phrase. ${ }^{183}$ Tellingly, the Singapore Constitutional Commission was composed mainly of English-trained lawyers, and "the proceedings were conducted entirely in English and the participants were mostly English-educated ... with absence of public discussion and scant press coverage." ${ }^{184}$ This is arguably unfortunate in a multi-linguistic society where the vast majority of the population did not understand English at that time. ${ }^{185}$

The 1966 Constitutional Commission made a conscious decision to adhere to the form and manner in which constitutional fundamental liberties were presented in the Constitution of Malaysia, departing only when "necessary and desirable."186 In the context of the religious liberty clause, the discussion was solely focused on whether the Malaysian constitutional restriction of religious propagation to Muslim adherents should be retained. ${ }^{187}$ Moving a level up, the Federation of Malaya Constitutional Commission report in relation to the original Constitution of Malaysia contains scant discussion about religious propagation as well. ${ }^{188}$ This is unlike the Indian Constituent Assembly, where the constitutional provision and importance of religious propagation was given

183 Li-ann Thio, “The Passage of a Generation: Revisiting the Report of the 1966 Constitutional Commission" in Li-ann Thio \& Kevin Y.L. Tan eds., Evolution of a Revolution: Forty Years of the Singapore Constitution (Routledge-Cavendish, 2009) at 7 ("In its genesis, the Singapore Constitution was not a product of mature deliberation or a broad-based popular, consultative process.”).

184 Ibid., at 11-12.

185 While statistics on the English literacy of the population during that period is not readily available, it is telling that even after nearly two decades of concerted government efforts in promoting the English language, only 33.7\% are literate in English in the 1970 population census, and 56.6\% indicating comprehension of English in a 1975 survey: S. Gopinathan, "Singapore Language Policies: Strategies for a Plural Society" (1979) 1979 Southeast Asian Affairs 280, 282; Eddie C.Y. Kuo, "Multilingualism and Mass Media Communications in Singapore” (1978) 18(10) Asian Survey 1067, 1068.

186 "Report of the Constitutional Commission 1966" in Kevin Tan Yew Lee et al., Constitutional Law in Malaysia \& Singapore (Malayan Law Journal, 1991), Appendix D, para. 14.

187 Ibid., at para. 38.

188 "Federation of Malaya Constitutional Commission, 1956-1957 Report" in Kevin Tan Yew Lee et al., Constitutional Law in Malaysia \& Singapore (Malayan Law Journal, 1991), Appendix A, para. 162 (It was a one-liner: "And we recommend (art 11) that freedom of religion should be guaranteed to every person including the right to profess practice and propagate his religion subject to the requirements of public order, health and morality, and that subject also to these requirements, each religious groups should have the right to manage its own affairs, to maintain religious or charitable institutions including schools, and to hold property for these purposes (art 12).”). The main debate on religion is about whether Islam should be designated as the state religion: Ibid., at para. 169. 
specific attention and debate. ${ }^{189}$ More importantly, the Malaysian constitutional restriction was rejected in Singapore on equality grounds without discussion of the importance or particularity of religious propagation. ${ }^{190}$ Hence, even if the original intent of the framers is given due emphasis, ${ }^{191}$ there is no guidance provided for Singapore's religious propagation restrictions based on the public order justification of religious harmony rather than the unequal protection of any particular religion. In addition, notwithstanding the Indian Constitution's express inclusion of the right to religious propagation, Indian courts have upheld laws that restrict certain forms of religious propagation ${ }^{192}$ with legal reasoning that echoed the Singapore court's emphasis on public order concerns when interpreting constitutional liberty. ${ }^{193}$

189 Robert W. Neufeldt, "To Convert or Not to Convert: Legal and Political Dimensions of Conversion in Independent India” in Robert D. Baird ed., Religion and Law in Independent India, 2nd ed. (Manohar, 2005) at 383-388; Li-ann Thio, "Contentious Liberty: Regulating Religious Propagation in a Multi-Religious Secular Democracy” (2010) S.J.L.S. at 494-496; Krishna Prasad De, Religious Freedom Under the Indian Constitution (Minerva Associates, 1977) at 46-47. See also Gurpreet Mahajan, "Religion and the Indian Constitution: Questions of Separation and Equality” in Rajeev Bhargava ed., Politics and Ethics of the Indian Constitution (Oxford University Press, 2008) at 297 (discussing the broader political backdrop and issues underpinning the Indian constitutional debate of religion).

190 "Report of the Constitutional Commission 1966" in Kevin Tan Yew Lee et al., Constitutional Law in Malaysia \& Singapore (Malayan Law Journal, 1991), Appendix D, para. 38.

191 See Li-ann Thio, “It Is a Little Known Legal Fact”: Originalism, Customary Human Rights Law and Constitutional Interpretation” (2010) 2010 S.J.L.S. 558, 569-570 (arguing for originalism in judicial interpretation of the Singapore Constitution). C.f., Yap Po Jen, “Constitutionalising Capital Crimes: Judicial Virtue or 'Originalism' Sin?” (2011) 2011 S.J.L.S. 281 (rebutting Thio on the normative desirability of originalism in the context of Singapore).

192 Robert W. Neufeldt, "To Convert or Not to Convert: Legal and Political Dimensions of Conversion in Independent India” in Robert D. Baird ed., Religion and Law in Independent India, 2nd ed. (Manohar, 2005) at 388-398 (discussing the relevant legislature at the three Indian provinces and the subsequent upholding by the courts); Robert D. Baird, "Traditional Values, Government Values, and Religious Conflict in Contemporary India” (1988) 1988 B.Y.U.L. Rev. 337, 351-354 (discussing the relevant legislature at the three Indian provinces and the subsequent upholding by the courts); James Andrew Huff, "Religious Freedom in India and Analysis of the Constitutionality of Anti-Conversion Laws" (2009) 10 Rutgers J.L. \& Religion 3, 7-13 \& 35-44.

193 Tsun Hang Tey, “Judicial Internalizing of Singapore’s Supreme Political Ideology” (2010) 40 Hong Kong L. J. 293, 320; Li-ann Thio, "Control, Co-optation and Co-operation: Managing Religious Harmony in Singapore's Multi-ethnic, Quasi-Secular State” (2006) 33 Hastings Const. L.Q. 209-210. 


\section{Reconciliation Under the Shadow of the Law}

Li-ann Thio provided a positive appraisal for the handling and resolution of the Lighthouse Evangelism incident. She singled out for praise the "responsible, repentant attitude of Pastor Tan"194 and noted with approval the "responsible, if not graceful" acceptance of the apology by the Buddhist and Taoist leaders ${ }^{195}$ and the calibrated government intervention. ${ }^{196}$ This combination of apology, forgiveness, and government intervention was highly regarded by other commentators writing in the press ${ }^{197}$ and reflects the official government narrative. ${ }^{198}$

Careful comparative examinations of the Pastor Tan and Pastor Ng incidents reveal additional nuances. First, the apologies by both pastors were initiated after the ISD had looked into the matter and contacted the relevant individual. Deputy Prime Minister Wong Kan Seng publicly noted that the ISD warning was no less serious than a police investigation. ${ }^{199}$ In any event, religious leaders in Singapore would probably need no additional reminders of the severity when the ISD is involved. The power of infinite detention without court trial under the ISD has been deployed against individuals on matters associated with religion. The specter of the Marxist conspiracy lingers, and the detention of radical Islamic terrorists over the past few years provides fresh reminders. ${ }^{200}$

Second, the initial apologies by Pastor Tan and Pastor Ng were declaratory statements posted on their respective church websites and were not well received by the religious leaders of the offended religions. In particular, the online apology by Pastor Ng was essentially rejected by Taoist leaders. ${ }^{201}$ It was after these reservations by the religious leaders were reported in the press that the personal visits were initiated. The personal visits to the Buddhist and Taoist leaders are crucial because the reconciliations took place at that stage.

194 Li-ann Thio, “Contentious Liberty: Regulating Religious Propagation in a Multi-Religious Secular Democracy” (2010) S.J.L.S at 502.

195 Ibid., at 504.

196 Li-ann Thio, "Contentious Liberty: Regulating Religious Propagation in a Multi-Religious Secular Democracy” (2010) S.J.L.S at 504-505.

197 William Goh, "Constant vigilance the answer" The Straits Times (11 February 2010); Wu Jungang, "Quebao zhongjiao hexie de youxing zhi shou [The visible hand that ensures religious harmony]" Lianhe Zaobao (10 February 2010).

198 Yen Feng, "Buddhist, Taoist leaders accept pastor's apology” The Straits Times (10 February 2010); "Need to deal with such problems quickly: PM" The Straits Times (16 February 2010); Kor Kian Beng, "Don't trivialise beliefs of others: SM Goh” The Straits Times (14 February 2010). 199 Chua Hian Hou, "Racist facebook postings: Three youths won't be charged” The Straits Times (13 February 2010).

200 Supra III.B.2.d.

201 Supra III.C.4. 
Third, although all of the religious leaders "spoke with a united voice, rejecting the making of insensitive comments against other religions and reiterating the common interest in religious harmony, "202 there is a difference in the religious leaders' statements. In addition to speaking out against insensitive conduct, Hindu and Buddhist religious leaders praised the authorities for the intervention and emphasised the need to prevent its recurrence. The Chairman of the Hindu Endowments Board was "glad to note" the vigilance of the ISD and hoped the insensitive conduct would not recur in the future. ${ }^{203}$ The Singapore Buddhist Federation also "applaud[ed] the timely involvement and advice by the relevant authorities" and hoped that the deeds would not be repeated. ${ }^{204}$ Such sentiments, absent from the reported comments of Christian and Muslim leaders, are perhaps unsurprising. The insensitive religious speeches by Pastor Tan and Pastor Ng are by no means one-off incidents. Indeed, their "offensive" religious speeches are relatively mild compared to some practices by other Christians. Although Pastor Ng compared Taoist deities to secret society gangsters, Chinese religious worship was compared to the worship of demons by another Singaporean Charismatic leader. ${ }^{205}$ A common critique in Christian religious propagation is the characterisation of other religions as false religions. ${ }^{206}$ Idol smashing, involving the destruction of Buddhist and Taoist artifacts, has been encouraged and sometimes mandated upon conversion, a thorny issue when other family members have not converted. ${ }^{207}$ The Pastor Tan and Pastor Ng incidents arguably reflect a longstanding frustration among the targeted reli-

202 Li-ann Thio, “Contentious Liberty: Regulating Religious Propagation in a Multi-Religious Secular Democracy” (2010) S.J.L.S. at 503. See also Li-ann Thio, "Relational Constitutionalism and the Management of Religious Disputes: the Singapore 'Secularism with a Soul' Model" (2012) Oxford J. L. \& Religion 1, 19-20.

203 "What Others Say About the Incident" The Straits Times (10 February 2010).

204 "Statements from Buddhist and Taoist Federations and DPM Wong Kan Seng" The Straits Times (10 February 2010).

205 Jean DeBernardi, “Asia’s Antioch: Prayer and Proselytism in Singapore” in Rosalind I.J. Hackett ed., Proselytization Revisited: Rights Talk, Free Markets and Culture Wars (Equinox, 2008) at 265.

206 Kuah-Pearce Khun Eng, State, Society and Religious Engineering: Towards a Reformist Buddhism in Singapore (Eastern Universities Press, 2003) at 272-277.

207 Jean DeBernardi, “Asia’s Antioch: Prayer and Proselytism in Singapore” in Rosalind I.J. Hackett ed., Proselytization Revisited: Rights Talk, Free Markets and Culture Wars (Equinox, 2008) at 266-267; Zakir Hussain, "Religious harmony: 20 years of keeping the peace” The Straits Times (24 July 2009). 
gious groups that is beginning to fester. ${ }^{208}$ Likewise, the distribution of materials criticising Islam is certainly not a new practice. As early as 2001, there were complaints of Muslims receiving articles criticising Islam in the mail and school children being given Bibles outside the school gates. ${ }^{209}$ The high-profile intervention by the government appears to be a welcome, possibly even overdue, relief for these targeted religions.

These considerations do not necessarily distract from the sincerity or genuineness of the apologies. Indeed, it is important to note that there appears to be genuine reconciliation between both sets of religious leaders. In particular, the Buddhist and Taoist leaders all reported being moved by the sincerity of Pastor Tan and Pastor Ng during their personal visits. ${ }^{210}$

Nonetheless, two takeaways emerge from this analysis. First, face-to-face meetings are important for genuine reconciliation and inter-faith religious harmony. "Many commentators view a face-to-face interaction between offender and offended as essential to effective expressions of remorse and apology."211 These interactions serve to enhance understanding between the two parties and to promote genuine reconciliation. ${ }^{212}$ These interactions are particularly important for groups that otherwise have little opportunity to interact under normal circumstances. $^{213}$ This point is relevant in Singapore, where the more conservative Christians often have reservations about interfaith interactions and cooperation with other religious organisations for fear that it may give the impression

208 Zakir Hussain, "Religious harmony: 20 years of keeping the peace” The Straits Times (24 July 2009) ("Ms Angie Monksfield, president of the Buddhist Fellowship, told Insight that the notice [about MHRA and notifying authorities] was put up 'in response to members' complaints [of unwanted proselytization and idol-smashing]...We've received complaints for years; we finally decided to do something about it.").

209 M. Nirmala, "Keeping faith - And celebrating differences” The Straits Times (12 May 2001). 210 Yen Feng, "Pastor says sorry and gains a friend" The Straits Times (17 June 2010); Yen Feng, "Buddhist, Taoist leaders accept pastor's apology" The Straits Times (10 February 2010).

211 Stephanos Bibas \& Richard A. Bierschbach, "Integrating Remorse and Apology into Criminal Procedure” (2004) 114 Yale L. Rev. 114, 114.

212 Robert D. Sloane, "The Expressive Capacity of International Punishment: the Limits of the National Law Analogy and the Potential of International Criminal Law” (2007) 43 Stan. J. Int'l L. 39, 86; Susan Sarnoff, "Restoring Justice to the Community: A Realistic Goal?” (2001) 65-JUN Fed. Probation 33, 34.

213 Gillian Lester, "Can Joe the Plumber Support Redistribution? Law, Social Preferences, and Sustainable Policy Design” (2011) 64 Tax L. Rev. 313, 373. See Martha Minow, "Education for Coexistence” (2002) 44 Ariz. L. Rev. 1, 13-15 (discussing the relatively successful integration experimental program in Israel for Jews and Palestinian Arab). 
that all religions are equal. ${ }^{214}$ It is noteworthy that this relationship-building function of face-to-face interactions remains even if the interactions take place under quasi-mandatory circumstances ${ }^{215}$ Moreover, although one may doubt the sincerity of apologies made under heavy government pressure, such "compelled" apologies are still better than none because these apologies can still serve as a vindication for the "victims" while facilitating the internalisation of norms for the "offender" by forcing the "offender" to acknowledge and confront the "wrongness" of his or her actions. ${ }^{216}$

Second, the heavily criticised draconian authoritarian legal sanctions and political hegemony are integral to these happy endings. Religious harmony is a constant emphasis by the ruling party that has maintained a firm hegemony over Singapore's political landscape. ${ }^{217}$ The implicit threat of sanctions from the executive branch, whether the ISD itself or under the MHRA, is unambiguously real and severe once the government has publicly taken a stance, as is the case when the ISD involvement is publicly reported. The intervention of the ISD would deter all but the most courageous (or defiant) religious leaders. This can be contrasted with cases of substantially more hateful protests by the Westboro Baptist Church and the Quran-burning antics of the Florida Pastor Terry Jones in the United States, where the public and political condemnation of those antics cannot be supported by legal sanctions given the free speech laws in the U.S. ${ }^{218}$ In contrast, the MHRA and the Internal Security Act would amply allow the Singapore government to treat the actions and speeches by the two pastors as liable for legal sanctions if the government wishes to pursue them. ${ }^{219}$

Notably, this backdrop of real sanctions not only provides a strong incentive for the offending religious leader to undertake the necessary remedial steps but also facilitates the forgiveness of the offended party. Local commentator Ang

214 Mathew Mathews, "Negotiating Christianity with Other Religions: The Views of Christian Clergymen in Singapore" in Lai Ah Eng ed., Religious Diversity in Singapore (Institute of Southeast Asian Studies, 2008) at 571, 581-582.

215 Gillian Lester, "Can Joe the Plumber Support Redistribution? Law, Social Preferences, and Sustainable Policy Design” (2011) 64 Tax L. Rev. at 373.

216 Stephanos Bibas \& Richard A. Bierschbach, "Integrating Remorse and Apology into Criminal Procedure” (2004) 114 Yale L. Rev. at 143.

217 Senia Febrica, "Securitizing Terrorism in Southeast Asia: Accounting for the Varying Responses of Singapore and Indonesia” (2010) 50(3) Asian Survey at 573-581; Tey Tsun Hang, "Excluding Religion from Politics and Enforcing Religious Harmony - Singapore-Style" (2008) 2008 S.J.L.S. at $120-125$.

218 Russell Adams, "Tensions still on boil in mosque fight" Wall Street Journal (13 September 2010) at A5; Jess Bravin \& Brent Kendall, "Supreme court wades into funeral protests" Wall Street Journal (9 March 2010) at A2.

219 Supra II.B.2.a \& II.B.2.d. 
Peng Hwa noted that the incidents reflect trust in the government and authorities because people turned to the authorities to mediate the responses. ${ }^{220}$ Indeed, the perceived strength of these sanctions gives confidence and comfort to the offended religious leaders and reduces the need to independently exert their displeasure or otherwise remedy matters themselves, even if the Buddhist and Hindus religious leaders still see the need for explicit reminders to avoid future incidents. Their sense of "insecurity"221 would likely be aggravated if the severity and reliability of the sanctions was doubted. In any event, it is ironic that the "relational constitutionalism" in Singapore ${ }^{222}$ discussed below ${ }^{223}$ is achieved in the shadow of the MHRA and the Internal Security Act, which are often criticised for undermining the constitutional protection of free speech and religious liberty. 224

\section{The atypical case of Singapore's proselytisation RESTRICTIONS}

The broad and occasionally harsh restrictions on religious propagation are certainly controversial. Criticism of Singapore's restrictions on offensive religious propagation reflects typical objections to proselytisation restrictions in general - namely, the discriminatory effect on minority religions and the harm to religious liberty and religious truth-seeking. In addition, local academics have proffered the argument that restricting religious propagation to secure social peace can be counterproductive given how these restrictions may induce "spiritual balkanisation" and impede "integration." This Part critically examines these

220 Ang Peng Hwa, “All S’poreans have role, not just leaders” The Straits Times (11 March 2010).

221 Li-ann Thio, "Constitutional 'Soft' Law and Management of Religious Liberty and Order: The 2003 Declaration on Religious Harmony” (2004) S.J.L.S. at 423; Li-ann Thio, “Control, Cooptation and Co-operation: Managing Religious Harmony in Singapore's Multi-ethnic, QuasiSecular State” (2006) 33 Hastings Const. L.Q. 239.

222 Li-ann Thio, "Relational Constitutionalism and the Management of Religious Disputes: the Singapore 'Secularism with a Soul' Model” (2012) Oxford J. L. and Religion at 22-24; Li-ann Thio, "Contentious Liberty: Regulating Religious Propagation in a Multi-Religious Secular Democracy” (2010) S.J.L.S. at 513.

223 Infra V.D.

224 Tey Tsun Hang, "Excluding Religion from Politics and Enforcing Religious Harmony Singapore-Style" (2008) 2008 S.J.L.S. at 137; Li-ann Thio, "Control, Co-optation and Co-operation: Managing Religious Harmony in Singapore’s Multi-ethnic, Quasi-Secular State” (2006) 33 Hastings Const. L.Q. at 233. 
objections to highlight their limitations before mounting a tentative defense of limited restrictions.

\section{A. The Dynamic of Majority-Minority Re-examined}

At first glance, the proselytisation restrictions in Singapore suggest a typical regulated religious market that is hostile toward religious minorities. The parties sanctioned in all four incidents were Christians propagating the Christian faith. With Christians constituting $18.3 \%$ of Singapore's population, ${ }^{225}$ it is not surprising that there are public musings by some Singaporean Christians that the Christian community is discriminated against in the regulations on offensive religious speeches. ${ }^{226}$ The status of Christians as a religious minority is an important theme in Li-ann Thio's narrative, justifying her call against the criminal prosecution of Pastor Tan, ${ }^{227}$ the potential need for sanctions against those who demanded legal sanctions against Pastor Tan, ${ }^{228}$ and the requirement of a "sense of proportion, tolerance and forgiveness" by the non-Christian recipients of offensive religious propagation. ${ }^{229}$

Upon closer examination, the numbers do not add up. Muslims, the religious community protected in the Ong Kian Cheong case and the Andrew Kiong

\section{Supra III.A.}

226 Alex Tan, "Double standards: In sedition case and DBS charity tie-up" The Straits Times (9 December 2008) (citing examples of the Da Vinci Code and Richard Dawkin's The God Delusion and arguing that "it is disheartening that this action [of maintaining the fragile religious balance] is not applied universally to all. There seems to be a greater tolerance of 'attacks' on Christianity than other major religions"). Although it is worth noting that Martin Scorsese's film, The Last Temptation of Christ, was previously banned in Singapore for offending Christian's sensitivities: Eugene K. B. Tan, "Keeping God in Place: The Management of Religion in Singapore” in Lai Ah Eng ed., Religious Diversity in Singapore (Institute of Southeast Asian Studies, 2008) at 67.

227 Li-ann Thio, "Contentious Liberty: Regulating Religious Propagation in a Multi-Religious Secular Democracy” (2010) S.J.L.S. at 505. See also Li-ann Thio, "Relational Constitutionalism and the Management of Religious Disputes: the Singapore 'Secularism with a Soul' Model" (2012) Oxford J. L. and Religion at 20.

228 Li-ann Thio, "Contentious Liberty: Regulating Religious Propagation in a Multi-Religious Secular Democracy" (2010) S.J.L.S. at 512. See also Li-ann Thio, "Relational Constitutionalism and the Management of Religious Disputes: the Singapore 'Secularism with a Soul' Model" (2012) Oxford J. L. and Religion at 20.

229 Li-ann Thio, "Contentious Liberty: Regulating Religious Propagation in a Multi-Religious Secular Democracy” (2010) S.J.L.S. at 512 (“[l]eaders of majority religious groups must demonstrate a sense of proportion, tolerance and forgiveness, towards leaders from minority religions who commit acts or make statements they find offensive, but who show genuine contribution"). 
cases, stand at $14.7 \%$ of the population, slightly less than the Christian population at $18.3 \%$. Taoists, implicated in the religious speeches by Pastor Tan and Pastor Ng, make up an even smaller community, at $10.9 \%$ of the population. The Buddhist population ratio of $33.3 \%$ exceeds the Christian population ratio, but it does not present Buddhism with an absolute majority or domineering numerical superiority over the Christian community. Li-ann's Thio religious minority narrative is achieved by combining the Buddhist and Taoist populations and pitting the combined $44.21 \%$ against the Christian minority of $18.3 \% .^{230}$ Li-ann Thio does not explain the rationale for this combination, ${ }^{231}$ although it is true that is often difficult to distinguish between Buddhism, Taoism, and Chinese traditional religion as practiced by the Chinese population in Singapore. ${ }^{232}$ Nonetheless, the Pastor $\mathrm{Ng}$ incident involved only Taoism ${ }^{233}$ and would not have fit into the narrative.

Christians are by no means a disadvantaged minority group in Singapore, either socially or economically. Despite constituting $18.3 \%$ of the population, Christians make up $32.2 \%$ of those holding university degrees ${ }^{234}$ and $35.4 \%$ of private property residents. ${ }^{235}$ The latter is a significant measure of wealth disparity, with the bulk of Singapore's households $(82.4 \%)$ residing in public subsidised HDB flats. ${ }^{236}$ The disproportionate representation in the upper

230 Li-ann Thio, "Relational Constitutionalism and the Management of Religious Disputes: the Singapore 'Secularism with a Soul' Model” (2012) Oxford J. L. and Religion at $1 \mathrm{nn} .1$ \& 19. See also Li-ann Thio, "Contentious Liberty: Regulating Religious Propagation in a Multi-Religious Secular Democracy” (2010) S.J.L.S. at 503 (“The response of representatives of majority religious groups.”). 231 One possible reason is that she was merely following the categorisation used in the table in the executive summary of the Singapore census 2010, which has a category "Buddhism/Taoism" with a sub-categories of "Buddhism" and "Taoism." Other religions such as "Christianity", "Islam" exist as independent category without any sub-category: Singapore Department of Statistics, Census of Population 2010 Statistical Release 1: Demographic Characteristics, Education, Language and Religion (2011) at 13. No particular reason or significance is attached to this categorisation by the census report. In the actual table, "Buddhism" and "Taoism" are independent categories, with "Taoism" including traditional Chinese beliefs: Ibid., at 154-155.

232 Jaime Koh \& Stephanie Ho, Culture and Customs of Singapore and Malaysia (Greenwood Press, 2009) at 32; Joseph B. Tamney \& Riaz Hassan, Religious Switching in Singapore: A Study of Religious Mobility (Select Books, 1987) at 6.

233 Unlike the Pastor Rony Tan incident, the Buddhist Federations was not involved in Pastor Mark Ng incident. Pastor Mark Ng only went to the Taoist Federations to apologise.

234 Singapore Department of Statistics, Census of Population 2010 Statistical Release 1: Demographic Characteristics, Education, Language and Religion (2011) at 16.

235 Ibid., at 159-160.

236 Singapore Department of Statistics, Census of Population 2010 Statistical Release 2: Households and Housing (2011) at xi. 
echelon of society was even starker in 1990 when, despite composing $12.7 \%$ of the population, Christians made up 39.3\% of the graduate population and $34.3 \%$ of the population living in private flats and houses. ${ }^{237}$ They are also strongly represented in different professions and in higher levels of civil service. ${ }^{238}$

These findings are in contrast with the religious communities that benefit from Singapore's restrictions. The census statistics indicate an underrepresentation of Muslims in these socio-economic indicators. Muslims represent $14.7 \%$ of the population, but they make up only $4.3 \%$ of those holding university degrees $^{239}$ and $3.2 \%$ of those residing in private property residences. ${ }^{240}$ Nevertheless, this is an improvement from the previous decade, when the 14.9\% Muslim population constituted 3.5\% of the graduate population and $2.8 \%$ of private property residents. ${ }^{241}$ The Buddhist and Taoist communities in Singapore face similar underrepresentation, albeit to a lesser degree. ${ }^{242}$

More crucially, the Christian community is by no means politically marginalised. In Singapore's Westminster parliamentary system, where the parliament is the primary political arena, ${ }^{243}$ publicly self-identified Christians make up $40 \%$ of the members of parliament in 2011. ${ }^{244}$ At least half of the new candidates of the incumbent ruling party in the most recent elections identified as Christians, and almost all were elected. ${ }^{245}$ Indeed, commentators have observed that

237 Leow Bee Geok, Census of Population 2000: Advance Data Release (2001) at 38.

238 John Clammer, The Sociology of Singapore Religion: Studies in Christianity and Chinese Culture (Chopmen, 1991) at 25; Kuah-Pearce Khun Eng, State, Society and Religious Engineering: Towards a Reformist Buddhism in Singapore (Eastern Universities Press, 2003) at 269.

239 Singapore Department of Statistics, Census of Population 2010 Statistical Release 1: Demographic Characteristics, Education, Language and Religion (2011) at 16.

240 Ibid., at 159-160.

241 Leow Bee Geok, Census of Population 2000: Advance Data Release (2001) at 38-40. The underrepresentation is even more severe in the 1960s and 1970s: John Clammer, Singapore: Ideology Society Culture (Chopmen, 1985) at 122-123.

242 With a population ratio of $10.9 \%$, Taoists only made up 5.3\% of those holding university degrees and $6.4 \%$ of those residing in private property. Buddhists, with $33.3 \%$ of the population, made up $23.6 \%$ of those holding university degrees and $11.5 \%$ of those residing in private property: Singapore Department of Statistics, Census of Population 2010 Statistical Release 1: Demographic Characteristics, Education, Language and Religion (2011) at 16 \& 159-160.

243 See Li-ann Thio, "Recent Constitutional Development: of Shadows and Whips, Race, Rifts and Rights, Terror and Tudungs, Women and Wrongs” (2002) 2002 S.J.L.S. 328, 329-334 (discussing Singapore parliamentary system).

244 Sam Holmes, "In Singapore, faith debate simmers as election nears” Wall Street Journal (7 May 2011) at A9.

245 Ibid.; "Li zongli: Zhengfu juebu yunxu guanyuan zhongjiao xingyang yingxiang zhengce [PM Lee: The government absolutely does not permit the religious faith of government officials to affect policy]" Lianhe Zaobao (17 April 2011) at 10. 
Christians exert "an influence, politically, socially and economically, far greater than the number they represent in the population."246

Christianity as a religion is not discriminated against in state assistance to religions. The Singapore government generally views religions in a positive light and as useful partners in the promotion of the common good (as defined by the state). ${ }^{247}$ Without the constraints of an Establishment Clause, charitable religious activities are actively encouraged by the government because "they represent the privatization of compassion, which is consonant with the government's anti-welfarism policy." 248 Education is one area of strong state-church cooperation, with the government providing substantial funding to religiously affiliated schools. Among the government-funded religiously affiliated schools, the vast majority are Christian mission schools. In 1998, there were 30 government-aided church-run primary schools and 29 government-aided church-run secondary schools, amounting to $15 \%$ of all primary and secondary schools in Singapore. ${ }^{249}$ In contrast, there was only one Buddhist secondary school and two Buddhist primary schools, with no schools affiliated with Taoism. ${ }^{250}$ Religious services and religious indoctrination are permitted in these religiously affiliated schools. Government funding only comes with a formal prohibition against compelling any student to attend mass or to receive religious instruction

246 Mathew Mathews, “Accommodating Relationship: The Church and State in Singapore” in Julius Bautista \& Francis Khek Gee Lim eds., Christianity and the State in Asia (Routledge, 2009) at 187; Jean DeBernardi, “Asia's Antioch: Prayer and Proselytism in Singapore” in Rosalind I.J. Hackett ed., Proselytization Revisited: Rights Talk, Free Markets and Culture Wars (Equinox, 2008) at 257.

247 Lydia Lim, "Religion should help people cope with change: PM" The Straits Times (23 June 2003); Li Xueying \& Keith Lin, "Does god get in the way of social cohesion” The Straits Times (21 October 2006).

248 Eugene K. B. Tan, “Keeping God in Place: The Management of Religion in Singapore” in Lai Ah Eng ed., Religious Diversity in Singapore (Institute of Southeast Asian Studies, 2008) at 69; Li-ann Thio, "Control, Co-optation and Co-operation: Managing Religious Harmony in Singapore's Multi-ethnic, Quasi-Secular State” (2006) 33 Hastings Const. L.Q. at 224; Kenneth Paul Tan, "Pragmatic Secularism, Civil Religion, and Political Legitimacy in Singapore" in Michael Heng Siam-Heng \& Ten Chin Liew eds., State and Secularism: Perspectives from Asia (World Scientific Publishing, 2010) at 339, 343.

249 Jason Tan, "The Politics of Religious Knowledge in Singapore Secondary Schools" in Catherine Cornbleth ed., Curriculum Politics, Policy, Practice: Cases in Comparative Context (State University of New York Press, 2000) at 77, 97 n.1.

250 Kuah-Pearce Khun Eng, State, Society and Religious Engineering: Towards a Reformist Buddhism in Singapore (Eastern Universities Press, 2003) at 282 (the first Buddhist mission secondary school was set up in 1984 to complement the existing two Buddhist mission primary schools); Joseph B. Tamney \& Riaz Hassan, Religious Switching in Singapore: A Study of Religious Mobility (Select Books, 1987) at 43. 
against the student's wishes. ${ }^{251}$ However, the religious influence and pressure in these schools ${ }^{252}$ arguably contributes to the correlation between attending such a school as a student and conversion to Christianity. ${ }^{253}$

Beyond direct substantive aid, Buddhism and Taoism do not enjoy much in the realm of state symbolism. The religious holidays of major religions are celebrated as official state holidays in Singapore, with government funding provided for public displays of holiday-related decorations. ${ }^{254}$ Among these official holidays, there are two for Christianity (Christmas and Good Friday), two for Islam (Hari Raya Puasa and Hari Raya Haji), one for Hinduism (Deepavali), and one for Buddhism (Vesak Day). Despite calls by the Taoist community for a religious holiday based on the birthday of Lao Zi (a key figure in Taoism), there is no official religious holiday for Taoism in Singapore. ${ }^{255}$ When the government introduced the Religious Knowledge curriculum in schools during the 1980s in an attempt to use religion to inculcate moral values among Singapore youths, Taoism was conspicuously absent from the curriculum, which included Christianity, Islam, Buddhism, and Hinduism. ${ }^{256}$

251 Constitution of the Republic of Singapore (1999 Rev. Ed), art. 15(4); Li Xueying \& Ken Kwek, "Say Aaah...men" The Straits Times (15 October 2005).

252 Jason Tan, "The Politics of Religious Knowledge in Singapore Secondary Schools" in Catherine Cornbleth ed., Curriculum Politics, Policy, Practice: Cases in Comparative Context (State University of New York Press, 2000) at 80; Trevor Ling, "Religion” in Kernial Singh Sandhu \& Paul Wheatley eds., Management of Success: the Moulding of Modern Singapore (Singapore: Institute of Southeast Asian Studies, 1989) at 692, 701. The Ministry of Education saw the need to "remind" missions schools in 1992 of the prohibition against compulsion in religious services: Janadas Devan, "Secularism - Not from theory but bloody history" The Straits Times (24 November 2007).

253 Chee Kiong Tong, Rationalizing Religion: Religious Conversion, Revivalism, and Competition in Singapore Society (Koninklijke Brill, 2007) at 102; Joseph B. Tamney \& Riaz Hassan, Religious Switching in Singapore: A Study of Religious Mobility (Select Books, 1987) at 12-13; John Clammer, Singapore: Ideology Society Culture (Chopmen, 1985) at 38; Kuah-Pearce Khun Eng, State, Society and Religious Engineering: Towards a Reformist Buddhism in Singapore (Eastern Universities Press, 2003) at 268.

254 Tan-Chow May Ling, Pentecostal Theology for the Twenty-First Century: Engaging with MultiFaith Singapore (Ashgate, 2007) at 10.

255 "Taoists Agree on Common Festive Day" The Straits Times (30 April 2001) at H3.

256 Chee Kiong Tong, Rationalizing Religion: Religious Conversion, Revivalism, and Competition in Singapore Society (Koninklijke Brill, 2007) at 249; Kuah-Pearce Khun Eng, State, Society and Religious Engineering: Towards a Reformist Buddhism in Singapore (Eastern Universities Press, 2003) at 196-197. For general discussion of the curriculum, see Li-ann Thio, "Control, Co-optation and Co-operation: Managing Religious Harmony in Singapore’s Multi-ethnic, Quasi-Secular State” (2006) 33 Hastings Const. L.Q. at 219-221; Jason Tan, "The Politics of Religious Knowledge in Singapore Secondary Schools" in Catherine Cornbleth ed., Curriculum Politics, Policy, Practice: Cases in Comparative Context (State University of New York Press, 2000). 
The case of Muslims is more complex. Legal academic Jaclyn Neo opined, "Singapore privileges Islam over other religions." ${ }^{257}$ She also expressed concern at the perceived bias in favour of the Malay-Muslim community in terms of the State's sanctions of offensive religious speech. ${ }^{258}$ Islamic religious practices are given special accommodation in Singapore. A special court administers Islamic law in matters of marriage, inheritance, and Islamic charitable trust property (wakaf). ${ }^{259}$ Muslim private religious schools (the madrasah) are given special and rare exemptions from the Compulsory Education Act. ${ }^{260}$ Muslim civil servants are allowed time off for Friday prayers. ${ }^{261}$ Furthermore, the land use authority ensures that there is at least one mosque in each new town. ${ }^{262}$ There is special statutory permission in the establishment of the Muslim Religious

257 Jaclyn Ling-Chien Neo, "The Protection of Minorities and the Constitution: A Judicious Balance?” in Li-ann Thio \& Kevin Y.L. Tan eds., Evolution of a Revolution: Forty Years of the Singapore Constitution (Routledge-Cavendish, 2009) at 234, 247.

258 Jaclyn Ling-Chien Neo, "Seditious in Singapore! Free Speech and the Offence of Promoting Ill-Will and Hostility Between Different Racial Groups” (2011) S.J.L.S. at 364-365.

259 Jaclyn Ling-Chien Neo, "The Protection of Minorities and the Constitution: A Judicious Balance?” in Li-ann Thio \& Kevin Y.L. Tan eds., Evolution of a Revolution: Forty Years of the Singapore Constitution (Routledge-Cavendish, 2009) at 247; Ahmad Nizam Abbas, "The fine balance of civil and syariah law in Singapore” The Straits Times (17 February 2008); Li-ann Thio, “'She's a Woman But She Acts Very Fast': Women, Religion and Law in Singapore” in Amanda Whiting \& Carolyn Evans eds., Mixed Blessings: Laws, Religions, and Women's Rights in the AsiaPacific Region (Martinus Nijhoff Publishers, 2006) at 241, 267-269.

260 Jaclyn Ling-Chien Neo, "The Protection of Minorities and the Constitution: A Judicious Balance?” in Li-ann Thio \& Kevin Y.L. Tan eds., Evolution of a Revolution: Forty Years of the Singapore Constitution (Routledge-Cavendish, 2009) at 254; Li-ann Thio, “'She's a Woman But She Acts Very Fast': Women, Religion and Law in Singapore” in Amanda Whiting \& Carolyn Evans eds., Mixed Blessings: Laws, Religions, and Women's Rights in the Asia-Pacific Region (Martinus Nijhoff Publishers, 2006) at 268. The exemption is subject to meeting government education standards for secular subjects such as English, Maths and Sciences. For a discussion of the historical evolution of Madrasah, see Sa'eda Buang, "Religious Education as Locus of Curriculum: A Brief Inquiry into Madrasah Curriculum in Singapore” in Lai Ah Eng ed., Religious Diversity in Singapore (Institute of Southeast Asian Studies, 2008) at 342.

261 Ahmad Osman, "Boosting integration in aftermath of tudung row" The Straits Times (10 February 2002); Li-ann Thio, "Recent Constitutional Development: of Shadows and Whips, Race, Rifts and Rights, Terror and Tudungs, Women and Wrongs” (2002) S.J.L.S. at 364; Li-ann Thio, "Control, Co-optation and Co-operation: Managing Religious Harmony in Singapore's Multi-ethnic, Quasi-Secular State” (2006) 33 Hastings Const. L.Q. at 214-215.

262 Li-ann Thio, "Constitutional 'Soft' Law and Management of Religious Liberty and Order: The 2003 Declaration on Religious Harmony” (2004) S.J.L.S. at 428; Li-ann Thio, "Control, Cooptation and Co-operation: Managing Religious Harmony in Singapore's Multi-ethnic, QuasiSecular State” (2006) 33 Hastings Const. L.Q. at 218; John Clammer, Singapore: Ideology Society Culture (Chopmen, 1985) at 45. 
Council of Singapore (Muis) to raise funds for the construction of mosques and to collect zakat (tithes) to administer Islamic charitable activities. ${ }^{263}$ On the level of international law, Singapore maintains reservations from various provisions of the Convention on the Elimination of All Forms of Discrimination Against Women (CEDAW) because of respect for the personal and religious beliefs of Muslim citizens under the Administration of Muslim Law Act. ${ }^{264}$ Such reservations are necessary given that Muslim polygamous marriage and the Islamic inheritance rule (a male should receive double the share of a female) are given legal recognition in Singapore. ${ }^{265}$ The recognition of Muslim polygamous marriage is particularly significant given that such exemptions were not given to the Chinese community even though polygamy can be arguably considered part of the Chinese religion of ancestral worship. ${ }^{266}$

Nonetheless, it is worth noting that academics elsewhere have argued for the normative desirability of giving extra protection to disadvantaged minorities. ${ }^{267}$ It is also possible to conceive of a version of religious equality that seeks

263 Jaclyn Ling-Chien Neo, "The Protection of Minorities and the Constitution: A Judicious Balance?” in Li-ann Thio \& Kevin Y.L. Tan eds., Evolution of a Revolution: Forty Years of the Singapore Constitution (Routledge-Cavendish, 2009) at 247; Li-ann Thio, “'She's a Woman But She Acts Very Fast': Women, Religion and Law in Singapore” in Amanda Whiting \& Carolyn Evans eds., Mixed Blessings: Laws, Religions, and Women's Rights in the Asia-Pacific Region (Martinus Nijhoff Publishers, 2006) at 268; Eugene K. B. Tan, "Keeping God in Place: The Management of Religion in Singapore” in Lai Ah Eng ed., Religious Diversity in Singapore (Institute of Southeast Asian Studies, 2008) at 62.

264 Braema Mathi, "UN convention on women: Govt has reservations" The Straits Times (11 July 2001) at H10; Li-ann Thio, "Control, Co-optation and Co-operation: Managing Religious Harmony in Singapore’s Multi-ethnic, Quasi-Secular State” (2006) 33 Hastings Const. L.Q. at 216; Jaclyn LingChien Neo, "The Protection of Minorities and the Constitution: A Judicious Balance?” in Li-ann Thio \& Kevin Y.L. Tan eds., Evolution of a Revolution: Forty Years of the Singapore Constitution (RoutledgeCavendish, 2009) at 255-256; Li-ann Thio, “'She's a Woman But She Acts Very Fast': Women, Religion and Law in Singapore” in Amanda Whiting \& Carolyn Evans eds., Mixed Blessings: Laws, Religions, and Women's Rights in the Asia-Pacific Region (Martinus Nijhoff Publishers, 2006) at 270-271.

265 Jaclyn Ling-Chien Neo, "The Protection of Minorities and the Constitution: A Judicious Balance?” in Li-ann Thio \& Kevin Y.L. Tan eds., Evolution of a Revolution: Forty Years of the Singapore Constitution (Routledge-Cavendish, 2009) at 254-255.

266 Li-ann Thio, “'She's a Woman But She Acts Very Fast': Women, Religion and Law in Singapore” in Amanda Whiting \& Carolyn Evans eds., Mixed Blessings: Laws, Religions, and Women's Rights in the Asia-Pacific Region (Martinus Nijhoff Publishers, 2006) at 253 (the colonial Straits Settlement Court of Appeal in 1911 recognised the religious nature of Chinese polygamous marriage).

267 Matthias Mahlmann, "Free Speech and the Rights of Religion" in András Sajó ed., Censorial Sensitivities: Free Speech and Religion in a Fundamentalist World (Eleven International Publishing, 2007) at 41, 67; Ruti Teitel, "Militating Constitutional Democracy: Comparative Perspectives" in András Sajó ed., Censorial Sensitivities: Free Speech and Religion in a Fundamentalist World (Eleven International Publishing, 2007) at 71, 77. 
to advance substantial equality through affirmative action in favour of traditionally disadvantaged minority groups. ${ }^{268}$ This is, in fact, enshrined in the Singapore Constitution; Article 152(1) expressly stipulates the government's responsibility to "constantly ... care for the interests of the racial and religious minorities in Singapore.” In addition, Article 152(2) provides, “[t]he Government shall exercise its functions in such manner as to recognise the special position of the Malays, who are the indigenous people of Singapore, and accordingly it shall be the responsibility of the Government to protect, safeguard, support, foster and promote their political, educational, religious, economic, social and cultural interests and the Malay language.”269 Similarly, Zhong Zewei suggested that in the circumstances of the systematic marginalisation of the Malay-Muslim community, the Ong Kian Cheong case may be justified as victim-centric hate speech. ${ }^{270}$ The Muslim community in Singapore is one of the most socially and economically disadvantaged religious communities in the country. Muslims do not enjoy over-representation in Parliament, unlike Christians. ${ }^{271}$ Indeed, only one of the 15 cabinet appointments is a Muslim. ${ }^{272}$ Even if the argument that Singapore's government affords special treatment and protection to Muslims is true, it is still very different from the typical scenario of a politically dominant religion oppressing other religions via state power.

In summary, Singapore's restrictions on proselytisation represent a significant departure from proselytisation restrictions elsewhere. The religious communities that are protected under the Singapore restrictions are not only small numerical minorities but also generally have lower socio-economic profiles. The Christian community, which has borne the brunt of the restrictions, is anything but a marginalised religious minority in Singapore, whether socially, economically, or politically.

268 Vincent D. Rougeau, Christians in the American Empire: Faith and Citizenship in the New World Order (Oxford University Press, 2008) at 101-109; Neera Chandhoke, Beyond Secularism: The Rights of Religious Minorities (Oxford University Press, 1999) at 143-165.

269 See Jaclyn Ling-Chien Neo, "The Protection of Minorities and the Constitution: A Judicious Balance?” in Li-ann Thio \& Kevin Y.L. Tan eds., Evolution of a Revolution: Forty Years of the Singapore Constitution (Routledge-Cavendish, 2009) at 240-248 (discussing the constitutional provision).

270 Zhong Zewei, "Racial and Religious Hate Speech in Singapore: Management, Democracy, and the Victim's Perspective" (2009) 27 Sing. L. Rev. at 52-53 \& 56.

271 Muslims made up 13 of the 99 members of parliament: <http://www.parliament.gov.sg/listof-current-mps> (last visited 20 July 2012).

272 Available at: <http://www.cabinet.gov.sg/content/cabinet/appointments.html> (last visited 20 July 2012). 


\section{B. Religious Liberty and Religious Truth-Seeking}

Although the argument of discrimination against politically vulnerable religious minorities is not applicable to Singapore, criticisms of infringing religious liberty and impeding religious truth-finding ${ }^{273}$ apply to Singapore's measures. Singapore's restrictions on proselytisation are a substantial impediment to the key tenet of Christianity as practiced in Singapore. Singaporean Christians are generally committed to evangelism ${ }^{274}$ and reject the liberal Protestant perspective that questions the appropriateness of proselytisation. ${ }^{275}$ In addition, the Protestant faith in Singapore is largely of the conservative and exclusivist school, which believes that its faith represents the absolute truth. ${ }^{276}$ Although Christians in Singapore appreciate that sensitivity to others' religions while proselytising may be practically more effective, ${ }^{277}$ the prohibition on critical commentary of other religions under the Singaporean restrictions risks violating their important religious tenet. ${ }^{278}$

273 Supra II.B.

274 Jean DeBernardi, “Asia’s Antioch: Prayer and Proselytism in Singapore” in Rosalind I.J. Hackett ed., Proselytization Revisited: Rights Talk, Free Markets and Culture Wars (Equinox, 2008) at 256-257; Tan-Chow May Ling, Pentecostal Theology for the Twenty-First Century: Engaging with Multi-Faith Singapore (Ashgate, 2007) at 22; Li Xueying, "Reaping a rich harvest of converts" The Straits Times (16 July 2005); Mathew Mathews, "Negotiating Christianity with Other Religions: The Views of Christian Clergymen in Singapore" in Lai Ah Eng ed., Religious Diversity in Singapore (Institute of Southeast Asian Studies, 2008) at 585-590.

275 Jean DeBernardi, “Asia's Antioch: Prayer and Proselytism in Singapore” in Rosalind I.J. Hackett ed., Proselytization Revisited: Rights Talk, Free Markets and Culture Wars (Equinox, 2008) at 257; Mathew Mathews, "Negotiating Christianity with Other Religions: The Views of Christian Clergymen in Singapore” in Lai Ah Eng ed., Religious Diversity in Singapore (Institute of Southeast Asian Studies, 2008) at 585-586. For observations and critique of the evolution of American Christians' attitude towards missions and proselytisation, see Brad A. Greenberg, "How missionaries lost their chariots of fire" Wall Street Journal (2 July 2010) at W9.

276 Mathew Mathews, “Accommodating Relationship: The Church and State in Singapore” in Julius Bautista \& Francis Khek Gee Lim eds., Christianity and the State in Asia (Routledge, 2009) at 188; Tan-Chow May Ling, Pentecostal Theology for the Twenty-First Century: Engaging with Multi-Faith Singapore (Ashgate, 2007) at 21-23.

277 Edmond Chua, "Bishop says preaches must watch sermon content, presentation" Christian Post (Sing. ed.) (23 September 2010), online: <http://sg.christianpost.com/dbase.php? cat=church\&id=2594> (last visited 1 February 2013); “Christianity: Winning Others or Helping Others Win?” Christian Post (Sing. ed.) (28 June 2010), online: <http://sg.christianpost.com/ dbase/editorial/732/section/1.htm> (last visited 1 February 2013).

278 Nathanael Ng, "Be sensitive, but do not compromise: Pastor” Christian Post (Sing. ed.) (23 February 2010), online <http://sg.christianpost.com/dbase.php?cat=church\&id=2444> (last visited 1 February 2013) (Cornerstone Community Church senior pastor Rev. Yang Tuck Yoong: "When preaching the Gospel, we must not dilute, adulterate or compromise on the potency of 
Similarly, religious truth-seeking is compromised under the Singapore measures. The recent incidents involve critical commentaries of other religions that fall short of hate speech. ${ }^{279}$ However, these debates about the truth of different religions are sanctioned under the Singapore measures. Indeed, notwithstanding the ostensible absence of legal sanctions, the Pastor Tan and Pastor Ng incidents are particularly troubling from religious truth-seeking perspectives given that the statements critical of other religions were made during sermons directed at their congregations. ${ }^{280}$ It can be envisaged that the Singapore measures have far-reaching, chilling effects on critical discussion relating to religions, both internally and publicly. This is certainly not conducive for a vigorous debate about the merits of different religions and the emergence of religious truth.

However, the diverse religious landscape of Singapore introduces important complexities to the applicability of these critiques, especially in light of the fact that Singapore's proselytisation restrictions do not represent the common practice of oppression of religious minorities by religious majorities. ${ }^{281}$ Indeed, close examination of the various religious outlooks of the different religions that make up Singapore's polity reveals a different set of underlying religious assumptions of proselytisation and truth-seeking that challenges the applicability of the critiques.

\section{Disparity in "Competitiveness" and Pressure to Compete}

While arguing for a church-state model in Singapore that envisaged different religions freely competing with one another for adherents without the interference of the State, ${ }^{282}$ Li-ann Thio acknowledged that religions that do not

the Word; because it's Truth,"); Roland Chia, "Christians do not hold that all religions are the same” Christian Post (Sing. ed.) (17 February 2010), online: <http://sg.christianpost.com/dbase/ editorial/593/section/1.htm> (last visited 1 February 2013); Tan Cheng Huat, "What would Jesus do (WWJD)?" Christian Post (Sing. ed.) (15 March 2010), online: <http://sg.christianpost.com/ dbase/editorial/604/section/1.htm> (last visited 1 February 2013) (“A series of happenings in recent weeks [Pastor Rony incident is in February 2010] drives me to rethink if our faith has reached such a point where the fear of imposing our views on others has gradually led us to a state where we do not profess clearly what we believe in.”).

279 Supra IV.A.

280 Supra IV.A.

281 Supra V.A.

282 Kevin Y.L. Tan \& Li-ann Thio, Constitutional Law in Malaysia and Singapore (Butterworths, 1997) at 876; Li-ann Thio, “Constitutional 'Soft' Law and Management of Religious Liberty and Order: The 2003 Declaration on Religious Harmony” (2004) S.J.L.S. at 422. 
espouse an objective truth may be at a competitive disadvantage. ${ }^{283}$ Barry A. Kosmin and Ariela Keysar also observed that "[e]xpanding the flock through evangelism is a core principle of Christianity and is a major force in a competitive system built on proselytizing."284 Many religions, in contrast, have a different religious outlook on proselytisation and religious competition. Proselytisation is a completely alien concept to animistic religions, which do not even have a concept of "religion" distinct from other rituals. ${ }^{285}$ Conversion and evangelism are conspicuously absent in Spiritualism. ${ }^{286}$ Other major world religions, such as Buddhism and Hinduism, do not share the evangelical zeal of their Christian and Muslim counterparts. ${ }^{287}$ An emphasis on evangelicalism is not even universal among Semitic religions; for example, external outreach is unimportant in Judaism. ${ }^{288}$

This diversity in religious worldviews is particularly salient in Singapore. The evangelistic zeal and commitment to exclusive truth of Singaporean Christians can be contrasted with the polytheistic religions of Hinduism, Taoism, and Buddhism, which have traditionally been non-proselytising as practiced in Singapore. ${ }^{289}$ For example, "[e]ven those [Buddhists] who recognize that the Singapore Chinese population is largely uninformed about Buddhism, and who see this as a problem, often do not consider it an urgent problem. For

283 Li-ann Thio, “Contentious Liberty: Regulating Religious Propagation in a Multi-Religious Secular Democracy” (2010) S.J.L.S. at 490 \& n. 38.

284 Barry A. Kosmin \& Ariela Keysar, Religion in a Free Market (Paramount Market Publishing, 2006) at 11.

285 Paul Harvey, "Proselytization" in Philip Goff \& Paul Harvey eds., Religion and American Culture (University of North Carolina Press, 2004) at 39, 41-42. For a discussion of the religious tenets and worldview of Sierra Leone indigenous religions, see Prince Sorie Conteh, Traditionalists, Muslims, and Christians in Africa (Cambria Press, 2009) at 19-62.

286 Deirdre Meintel, "When There is No Conversion: Spiritualists and Personal Religious Change” (2007) 49(1) Anthropologica 149, 149.

287 Jeff Spinner-Haley, "Hinduism, Christianity, and Liberal Religious Toleration” (2005) 33(1) Political Theory 28, 37; Kuah-Pearce Khun Eng, State, Society and Religious Engineering: Towards a Reformist Buddhism in Singapore (Eastern Universities Press, 2003) at 137; Chee Kiong Tong, Rationalizing Religion: Religious Conversion, Revivalism, and Competition in Singapore Society (Koninklijke Brill, 2007) 152-153.

288 Grace Y. Kao, "The Logic of Anti-proselytization, Revisited” in Rosalind I.J. Hackett ed., Proselytization Revisited: Rights Talk, Free Markets and Culture Wars (Equinox, 2008) at 83-84; Paul Harvey, "Proselytization” in Philip Goff \& Paul Harvey eds., Religion and American Culture (University of North Carolina Press, 2004) at 56-57.

289 Kuah-Pearce Khun Eng, State, Society and Religious Engineering: Towards a Reformist Buddhism in Singapore (Eastern Universities Press, 2003) at 137; Chee Kiong Tong, Rationalizing Religion: Religious Conversion, Revivalism, and Competition in Singapore Society (Koninklijke Brill, 2007) at 152-153). 
centuries Buddhist monks have accepted the idea that people require a variety of religious traditions." ${ }^{290}$ The key Taoist tenet of $w u$ wei, "action through inaction," accounts for the relatively passive attitude by Taoist adherents toward the decline in numbers. ${ }^{291}$ Proselytising is discouraged by the official Hindu organisation in Singapore. ${ }^{292}$ Even the Muslim community in Singapore has not displayed a significant evangelical orientation. ${ }^{293}$

It must be recognised that given the prestige and material resources associated with larger congregations, there are incentives even for non-proselytising religions to seek to increase their membership. ${ }^{294}$ Nonetheless, there is still a disparity in motivation between the proselytising and non-proselytising religions. $^{295}$

Moreover, the issue is not simply about the disparity in competitiveness. Li-ann Thio noted that in response to the constitutional right to religious propagation, "religious groups are entitled ... to take self-preservationist measures." 296 Indeed, the "competitive pressure" from proselytising religions has caused formerly non-proselytising religions to proselytise $\mathrm{e}^{297}$ or otherwise react defensively. ${ }^{298}$ Buddhists and Taoists in Singapore, in reaction to the steady

290 Joseph B. Tamney \& Riaz Hassan, Religious Switching in Singapore: A Study of Religious Mobility (Select Books, 1987) at 43.

291 "The Way of the Future" The Straits Times (19 June 2010).

292 Arti Mulchand, "Religion: The big switch" The Straits Times (9 August 2008) (“conversion to Hinduism is 'downright impossible', says the Hindu Endowments Board on its website. It is a faith one is born into, though there are a minority who choose to take on and practice the tenets of Hinduism").

293 Kuah-Pearce Khun Eng, State, Society and Religious Engineering: Towards a Reformist Buddhism in Singapore (Eastern Universities Press, 2003) at 137.

294 R. Andrew Chesnut, Competitive Spirits: Latin America's New Religious Economy (Oxford University Press, 2003) at 11; Barry A. Kosmin \& Ariela Keysar, Religion in a Free Market (Paramount Market Publishing, 2006) at 170-171.

295 R. Andrew Chesnut, Competitive Spirits: Latin America's New Religious Economy (Oxford University Press, 2003) at 11.

296 Li-ann Thio, “Contentious Liberty: Regulating Religious Propagation in a Multi-Religious Secular Democracy” (2010) S.J.L.S. at 515.

297 Jean-Francois Mayer, "Conflicts over Proselytism: An Overview and Comparative Perspective" in Rosalind I.J. Hackett ed., Proselytization Revisited: Rights Talk, Free Markets and Culture Wars (Equinox, 2008) at 35, 46-48; Rachelle M. Scott, "Promoting World Peace through Inner Peace: The Discourses and Technologies of Dhammakāya Proselytization” in Rosalind I.J. Hackett ed., Proselytization Revisited: Rights Talk, Free Markets and Culture Wars (Equinox, 2008) at 231, 235-236.

298 Stephen C. Berkwitz, "Religious Conflict and the Politics of Conversion in Sri Lanka" in Rosalind I.J. Hackett ed., Proselytization Revisited: Rights Talk, Free Markets and Culture Wars (Equinox, 2008) at 203-204; Thomas Robbins, "Notes on the Contemporary Peril to Religious 
decline of their numbers that mirrored gains by Christians, ${ }^{299}$ have strengthened their organisation and have begun programs to proselytise. ${ }^{300}$ It is crucial to recognise that these "self-preservationist measures" represent changes to the existing religious tenets and practices of religions that have previously shunned such organisation and proselytisation activities. ${ }^{301}$

These changes and the pressure that induced them are not necessarily negative. If previously non-proselytising religions are compelled to participate in religious competition, individuals will be presented with more information regarding a greater variety of religions and religious practices. The articulation of one's beliefs in the process of religious propagation also facilitates the re-examination of those beliefs; one often must persuade oneself before persuading others. All of these factors enable a more informed decision about religious choice and facilitate religious truth-seeking. The problem, as will be examined in the next section, is that the religious truth-seeking justification itself rests on assumptions that are specific to some religions only.

\section{Religious Truth-Seeking}

In addition to treating the behavior-modifying pressure exerted on non-proselytising religions as a positive development, the religious truth-seeking justification is an important counterweight to restricting religious propagation that may otherwise be offensive or harmful. Echoing the "marketplace of ideas" justification of free speech, ${ }^{302}$ the potentially disconcerting and unsettling effect on the recipients of this "offensive" religious propagation must be balanced by the

Freedom" in James A. Beckford \& James T. Richardson eds., Challenging Religion (Routledge, 2003) at 71, 73; Tessa Bartholomeusz, "First Among Equals: Buddhism and the Sri Lankan State" in Ian Harris ed., Buddhism and Politics in Twentieth-Century Asia (Pinter, 1999) at 173, 176-177.

299 Supra III.A.

300 Chee Kiong Tong, Rationalizing Religion: Religious Conversion, Revivalism, and Competition in Singapore Society (Koninklijke Brill, 2007) at 192 \& 267-268; John Clammer, The Sociology of Singapore Religion: Studies in Christianity and Chinese Culture (Chopmen, 1991) at 74-77; KuahPearce Khun Eng, State, Society and Religious Engineering: Towards a Reformist Buddhism in Singapore (Eastern Universities Press, 2003) at 283.

301 Supra notes 289-293 and accompany text.

302 Geoffrey R. Stone et al., Constitutional Law, 5th ed. (Aspen Publishers, 2005) at 1054-1056; William P. Marshall, "Truth and Religion Clauses" (1994) 43 DePaul L. Rev. at 256; Lawrence Rosenthal, "First Amendment Investigations and the Inescapable Pragmatism of the Common Law of Free Speech” (2011) 86 Ind. L.J. at 61-62 \& 61 n. 288; Steven G. Gey, “The First Amendment and the Dissemination of Socially Worthless Untruths” (2008) 36 Fla. St. U.L. Rev. at 6-9. 
need to facilitate the emergence of religious truth through free competition among the different religions. ${ }^{303}$

Many religions, such as Christianity and Islam, are predicated on exclusive claims of religious truth and place enormous emphasis on religious truth-seeking. ${ }^{304}$ However, not all religions are predicated on truth claims. ${ }^{305}$ For example, Hinduism does not claim an exclusive $\operatorname{truth}^{306}$ and does not posit salvation through faith in a true religion. ${ }^{307}$ This ambivalence toward religious truthseeking is reflected in Buddhism ${ }^{308}$ and $\mathrm{Taoism}^{309}$ as well. Inherent in

303 Daniel O. Conkle, "Religious Truth, Pluralism, and Secularization: The Shaking Foundations of American Religious Liberty” (2011) 32 Cardozo L. Rev. at 1757-1762; Li-ann Thio, “Contentious Liberty: Regulating Religious Propagation in a Multi-Religious Secular Democracy” (2010) S.J.L.S. at 493; M.H. Ogilvie, "Between Liberté and Égalité: Religion and the State in Canada" in Peter Radan et al. eds., Law and Religion: God, the State and the Common Law (Routledge, 2005) at 154; William P. Marshall, “Truth and Religion Clauses” (1994) 43 DePaul L. Rev. at 255-256.

304 Sarah Claerhout \& Jakob De Roover, "Conversion of the World: Proselytization in India and the Universalization of Christianity” in Rosalind I.J. Hackett ed., Proselytization Revisited: Rights Talk, Free Markets and Culture Wars (Equinox, 2008) at 53, 65. For a discussion on the exclusivity under Islam, see Heather J. Sharkey, "Muslim Apostasy, Christian Conversion, and Religious Freedom in Egypt: A Study of American Missionaries, Western Imperialism, and Human Rights Agendas” in Rosalind I.J. Hackett ed., Proselytization Revisited: Rights Talk, Free Markets and Culture Wars (Equinox, 2008) at 139, 141.

305 Sarah Claerhout \& Jakob De Roover, “Conversion of the World: Proselytization in India and the Universalization of Christianity" in Rosalind I.J. Hackett ed., Proselytization Revisited: Rights Talk, Free Markets and Culture Wars (Equinox, 2008) at 65. See generally S.A. Nigosian, World Religions: A Historical Approach, 3rd ed. (Bedford/St. Martin's, 2000) at 414-419 (discussing how the different religions differ in their conceptions of religious path and goals).

306 P.N. Bhagwati, "Religion and Secularism Under the Indian Constitution" in Robert D. Baird ed., Religion and Law in Independent India, 2nd ed. (Manohar, 2005) at 35, 39; Tan Chin Liew, "Secularism and Its Limits" in Michael Heng Siam-Heng \& Ten Chin Liew eds., State and Secularism: Perspectives from Asia (World Scientific Publishing, 2010) at 7, 18; Daniel 0. Conkle, "Religious Truth, Pluralism, and Secularization: The Shaking Foundations of American Religious Liberty” (2011) 32 Cardozo L. Rev. at 1764; Jeff Spinner-Haley, "Hinduism, Christianity, and Liberal Religious Toleration" (2005) 33(1) Political Theory at 37.

307 P.N. Bhagwati, "Religion and Secularism Under the Indian Constitution" in Robert D. Baird ed., Religion and Law in Independent India, 2nd ed. (Manohar, 2005) at 39; Tan Chin Liew, "Secularism and Its Limits" in Michael Heng Siam-Heng \& Ten Chin Liew eds., State and Secularism: Perspectives from Asia (World Scientific Publishing, 2010) at 18.

308 Daniel O. Conkle, "Religious Truth, Pluralism, and Secularization: The Shaking Foundations of American Religious Liberty” (2011) 32 Cardozo L. Rev. at 1764-1765 (noting how Buddhism's de-emphasis of universal truth contributes to its more tolerant attitude towards other faith).

309 See generally Francisca Cho, "Leaping into the Boundless: A Daoist Reading of Comparative Religious Ethics” (1998) 26(1) The Journal of Religious Ethics 139 (discussing and noting Taoism nuanced approach towards truth, reflecting at page 163 "[T]aoist view of reality which avers that knowledge is never fixed."). 
Christianity and Islam's emphases on evangelicalism is the notion that other religions are rivals with which one must actively compete. ${ }^{310}$ In contrast, Hindu, Jain, and Buddhist traditions view other religions not as religious rivals but simply as different ways within different contexts of reaching salvation. ${ }^{311}$

This divergence in religious outlooks is particular salient in Singapore, where Buddhism, Taoism, and Hinduism make up $49.3 \%$ of the population. ${ }^{312}$ In the aftermath of the Pastor Tan incident, the secretary-general of the Singapore Buddhist Federation, Venerable Kwang Phing, observed, "Singapore is a multi-religious, multiracial society. There is no point arguing over who is right and who is wrong." 313 This contrast in conceptualisation can be further epitomised by the following two statements from the religious leaders of the two major religious organisations in Singapore. Dr. Robert Solomon (president of the National Council of Churches of Singapore) opined, "[f]rom the Church perspective, we understand religious harmony not so much as harmony of religion because we think that route is very theoretical and doctrinal and has many problems anyway...It makes us more relaxed if we define religious harmony as harmony among people of different faiths living in a multi-religious society." 314 In contrast, Venerable Kwang Sheng (president of Singapore Buddhist Federation) had little reservation about the perception of "religious equality" and noted, "Buddhism advocates respect for other religions and acceptance of others' values. Peace and happiness in a society can be achieved only through an appreciation of the different faiths." 315 Together with the Singapore Muslim

310 Sarah Claerhout \& Jakob De Roover, "Conversion of the World: Proselytization in India and the Universalization of Christianity" in Rosalind I.J. Hackett ed., Proselytization Revisited: Rights Talk, Free Markets and Culture Wars (Equinox, 2008) at 63-64 ("Islam and Christianity are each other's rivals in the restoration of divine truth, while the Hindu, Buddhist and Jain traditions are idolatry or false religion."); Tan-Chow May Ling, Pentecostal Theology for the Twenty-First Century: Engaging with Multi-Faith Singapore (Ashgate, 2007) at 22-23; Jean DeBernardi, "Asia's Antioch: Prayer and Proselytism in Singapore" in Rosalind I.J. Hackett ed., Proselytization Revisited: Rights Talk, Free Markets and Culture Wars (Equinox, 2008) at 265; Kuah-Pearce Khun Eng, State, Society and Religious Engineering: Towards a Reformist Buddhism in Singapore (Eastern Universities Press, 2003) at 272-277.

311 Sarah Claerhout \& Jakob De Roover, "Conversion of the World: Proselytization in India and the Universalization of Christianity" in Rosalind I.J. Hackett ed., Proselytization Revisited: Rights Talk, Free Markets and Culture Wars (Equinox, 2008) at 64-65.

312 Singapore Department of Statistics, Census of Population 2010 Statistical Release 1: Demographic Characteristics, Education, Language and Religion (2011) at 13.

313 Grace Chua, "Leaders of Buddhist, Taoist groups urge restraint" The Straits Times (9 February 2010).

314 "We Need to Focus More on Common Spaces” The Straits Times (21 October 2006).

315 "Foster Harmony” The Straits Times (3 May 2009). 
community, which does not display a strong evangelical outlook, it is arguable that the majority of Singapore's religious adherents do not share the emphasis on religious truth-seeking.

\section{Summary: The Contested Assumptions of Religious Truth-Seeking}

Religious truth-seeking, despite its attractiveness as a normative principle, is based on religious assumptions that are not shared by other religious outlooks. As acknowledged by William P. Marshall, who otherwise advocated for religious truth-seeking as a normative guiding principle, "[f]or other religions truth may not be a meaningful concept, and to them the search for truth might be seen as something that is largely irrelevant." 316 In the context of Singapore where there is no broad acceptance of religious truth-seeking as a normative goal among the diverse religious outlooks of the polity, the case for tolerating offensive religious propagation is deprived of this otherwise compelling justification.

\section{Spiritual Balkanisation and Religious Harmony in a Religiously Pluralistic Society}

If consensus among the different religions is not possible and the design of laws on religious propagation would inevitably favour either the truth-predicating religions or their non-evangelical competitors, ${ }^{317}$ a possible way forward is to rely on justifications that are not predicated on assumptions about religion. Religious and racial harmony has been a perpetual obsession of Singapore's government as an integral condition for the survival of the young nation State. ${ }^{318}$ Religious and racial riots in the past have been a prominent feature in the government's arguments for strict state controls over religions. ${ }^{319}$ Although commentators have expressed skepticism about the precariousness of religious

316 William P. Marshall, “Truth and Religion Clauses” (1994) 43 DePaul L. Rev. at 265.

317 Sarah Claerhout \& Jakob De Roover, "Conversion of the World: Proselytization in India and the Universalization of Christianity” in Rosalind I.J. Hackett ed., Proselytization Revisited: Rights Talk, Free Markets and Culture Wars (Equinox, 2008) at 69.

318 Li-ann Thio, "Control, Co-optation and Co-operation: Managing Religious Harmony in Singapore’s Multi-ethnic, Quasi-Secular State” (2006) 33 Hastings Const. L.Q. at 202.

319 Jean DeBernardi, “Asia's Antioch: Prayer and Proselytism in Singapore” in Rosalind I.J. Hackett ed., Proselytization Revisited: Rights Talk, Free Markets and Culture Wars (Equinox, 2008) at 261. 
relations in Singapore, ${ }^{320}$ frequent reports of religious strife in other religiously pluralistic societies ${ }^{321}$ affirm the validity and importance of social harmony as a consideration. In this regard, Li-ann Thio warned that restricting evangelism to secure social peace may be counterproductive because such restrictions may result in "spiritual balkanisation" that deepens social rifts when a committed evangelical religionist begins to view "non-members as 'others' to be shunned rather than as 'brothers and sisters who need to be turned to the truth." 322 This is echoed by Jaclyn Ling-Chien Neo, who, in the discussion of the Ong Kian Cheong case, opined that "[r]epressing open communication may lead to suspicion, resentment and division, thereby impeding true integration and the creation of a true community." 323

In this regard, the premise of criticisms about "spiritual balkanisation" or "integration" is flawed. Jaclyn Neo argued that the "creation of a true community ... requires some measure of free, open and reasoned debate about racial and religious differences, and how to possibly bridge those differences and foster a commitment to a shared identity." 324 This assumes that religious adherents who are committed to religious propagation and pro-active proselytisation are eager to utilise the freedom of religious propagation to engage other religions in dialogue about bridging differences and fostering a shared identity. This assumption does not gel with the actual motivation of most proselytising activities (especially the sanctioned offensive religious propagation in Singapore), in which conversion and renunciation of the former religious identity are typically the "endgame of religious propagation." 325 If anything, religious propagations that are highly critical of other religions not only serve to reinforce the stark and unbridgeable differences between religious communities but also highlight that the propagating community views the recipient community negatively and, depending on the harshness and tone of the materials, as a

320 Michael Hill, "The Making of a Moral Panic: Religion and State in Singapore” in James A. Beckford \& James T. Richardson eds., Challenging Religion (Routledge, 2003) at 114, 125. See also Li-ann Thio, "Control, Co-optation and Co-operation: Managing Religious Harmony in Singapore's Multi-ethnic, Quasi-Secular State” (2006) 33 Hastings Const. L.Q. at 202.

321 E.g., Drew Hinshaw, "Nigeria torn by rising religious violence" Wall Street Journal (12 January 2012) at A12; Patrick Barta, "Suicide attack strikes Church in Indonesia” Wall Street Journal (26 September 2011) at A10.

322 Li-ann Thio, "Contentious Liberty: Regulating Religious Propagation in a Multi-Religious Secular Democracy” (2010) S.J.L.S. at 493.

323 Jaclyn Ling-Chien Neo, "Seditious in Singapore! Free Speech and the Offence of Promoting Ill-Will and Hostility Between Different Racial Groups” (2011) S.J.L.S. at 371-372.

324 Ibid., at 365-372.

325 Li-ann Thio, “Contentious Liberty: Regulating Religious Propagation in a Multi-Religious Secular Democracy” (2010) S.J.L.S. at 488. 
dangerous threat to overall society. ${ }^{326}$ Similarly, the threat of "spiritual balkanisation" alluded to by Li-ann Thio is just as likely if her hypothetical committed religionist is allowed to continue to propagate the faith but treats those non-members who stubbornly refuse to accept the truth as "others" to be shunned.

Indeed, the experience in Singapore proves contrary to such concerns. First, the deep commitment to convert others has not translated into genuine interfaith interactions and understanding. Christian scholars have indicated that non-Catholic Protestant Christians in Singapore traditionally adopt a conservative religious outlook that "shun[s] any attempt to compromise this exclusivity." 327 One way that this exclusivity manifests is the evangelistic fervor by which the Church "takes pains to ensure that its market share within the religious economy is growing, an indication that it is heeding the divine mandate to reach as many people as possible with the Christian message." 328 This eagerness to treat other members of the population as "brothers and sisters who need to be turned to the truth" ${ }^{329}$ has not resulted in more harmonious relationships with other religious communities. On the contrary, these sentiments may actually impede inter-religious interactions in a multi-religious society. In a poll of 183 clergymen, 41.5\% "[found] it difficult to collaborate with a non-Christian religious leader for a charity drive. They fear it would lead to the perception that 'all religions are equal.,"330 Such reservations exist for participation in interfaith dialogue with other religions as well. ${ }^{331}$ Based on interviews with Christian

326 One material distributed in the Ong Kian Cheong case stated that there is a "very dangerous religion called 'Islam"' that is "spreading into our neighborhood" (emphasis original): Jack T. Chick, Little Bride (Chick Publications, 2004), online: <http://www.chick.com/reading/tracts/ 1054/1054_01.asp> (last visited 1 February 2013).

327 Mathew Mathews, “Accommodating Relationship: The Church and State in Singapore” in Julius Bautista \& Francis Khek Gee Lim eds., Christianity and the State in Asia (Routledge, 2009) at 188; Tan-Chow May Ling, Pentecostal Theology for the Twenty-First Century: Engaging with Multi-Faith Singapore (Ashgate, 2007) at 21-23.

328 Mathew Mathews, “Accommodating Relationship: The Church and State in Singapore” in Julius Bautista \& Francis Khek Gee Lim eds., Christianity and the State in Asia (Routledge, 2009) at 188.

329 Li-ann Thio, “Contentious Liberty: Regulating Religious Propagation in a Multi-Religious Secular Democracy” (2010) S.J.L.S. at 493.

330 Mathew Mathews, "Negotiating Christianity with Other Religions: The Views of Christian Clergymen in Singapore" in Lai Ah Eng ed., Religious Diversity in Singapore (Institute of Southeast Asian Studies, 2008) at 581-582; Li Xueying, "Clergy 'wary of inter-faith talks"” The Straits Times (3 September 2008).

331 Tan-Chow May Ling, Pentecostal Theology for the Twenty-First Century: Engaging with MultiFaith Singapore (Ashgate, 2007) at 21. 
leaders in 2004, Jean DeBernardi noted that "[a]lthough some Christian leaders have welcomed the opportunity for greater dialogue with non-Christians (in particular Muslim leaders), others participate grudgingly or delegate the responsibility to others." 332 "One reason the clergy is apprehensive is the fear that the media will 'misrepresent' such dialogues as an admission that 'all religions are one." 333

This aversion to inter-faith interactions limits face time and relationship building among the different religions. As noted in the Pastor Tan and Pastor $\mathrm{Ng}$ incidents, face-to-face interactions between religious leaders of different faiths are essential for genuine reconciliation. The initial declaratory apology posted online would have been insufficient to bridge the inter-religious rifts. Moreover, an exclusivist outlook by a religious community is likely to prompt negative reactions from other religious communities, who, despite being otherwise accommodating on religious matter, may draw a line from the exclusive religious community. This dynamic can be seen in a 2008 incident in which a local bank withdrew a charity tie-in promotion with Focus on the Family, a local voluntary welfare organisation with links to the conservative Christian organisation in the United States, ${ }^{334}$ after complaints by members of the public that "the charity's United States parent organization, and its Singapore arm, are anti-gay, anti-abortion and pro-abstinence." ${ }^{335}$ The president of Focus on the Family (Singapore) wrote to the media expressing concerns about the bank's withdrawal based upon complaints by small group of activists and argued that the charity "function[s] akin to other faith-based organizations such as the Thye Hua Kwan Moral Society and Care Corner Family Service Centre in Singapore, or World Vision and YMCA internationally." 336 However, instead of standing together with a fellow religious organisation, as one might expect given the purported culture war waged by anti-religious militant secularists against

332 Jean DeBernardi, “Asia’s Antioch: Prayer and Proselytism in Singapore” in Rosalind I.J. Hackett ed., Proselytization Revisited: Rights Talk, Free Markets and Culture Wars (Equinox, 2008) at 261.

333 Andy Ho, "Interfaith dialogue: Why some clam up” The Straits Times (18 September 2008); Mathew Mathews, "Accommodating Relationship: The Church and State in Singapore” in Julius Bautista \& Francis Khek Gee Lim eds., Christianity and the State in Asia (Routledge, 2009) at 193. 334 For a detailed discussion of the activities (including political activities) of Focus of the Family in the US: see Dan Gilgoff, The Jesus Machine: How James Dobson, Focus on the Family and Evangelical America are Winning the Culture War (St Martin's Press, 2007).

335 Grace Chua, “DBS’ charity tie-up draws flak” The Straits Times (5 December 2008). 336 Ibid. 
religion, ${ }^{337}$ the Thye Hua Kwan Moral Society (a Taoist charity) promptly wrote to the press to clarify and distance itself from association with Focus on the Family. In particular, the Society emphasised its respectful and accommodating attitudes toward other religions, ${ }^{338}$ a less-than-subtle reference and rebuttal of the perceived exclusive religious outlook of conservative Christian charitable organisations.

Indeed, notwithstanding the conspicuous lack of evangelical zeal, Buddhist and Taoist charitable organisations in Singapore are traditionally more willing to work with religious charitable organisations that are affiliated with other faiths. Although it is common practice for religious organisations in Singapore to provide welfare services regardless of race or religion, Buddhist groups in Singapore go further and are comfortable donating directly to charitable groups of other religions. ${ }^{339}$ Buddhist and Taoist religious organisations also readily cater to different religious requirements in their provision of charitable services, ${ }^{340}$ such as the special provision of halal food during the regular distribution of free meals by the Thye Hua Kwan Moral Society (Taoist). ${ }^{341}$ This approach has been praised by the government for its contribution to racial and religious harmony, ${ }^{342}$ and some Muslim organisations have recently begun to

337 E.g., Edmond Chua, "Militant secularists demand Rony Tan's arrest” Christian Post (Sing. ed.) (11 February 2010), online: <http://sg.christianpost.com/dbase.php?cat=church\&id=2563> (last visited 1 February 2013); Li-ann Thio, “Control, Co-optation and Co-operation: Managing Religious Harmony in Singapore’s Multi-ethnic, Quasi-Secular State” (2006) 33 Hastings Const. L.Q. at 225 n. 170.

338 In the press statement, the Taoist charity emphasised that the society is "happy that people from diverse cultural and religious backgrounds feel comfortable using our services," "aim[s] to provide culturally-sensitive services that our clients' values and beliefs," and "all our Centres and Homes observe equally the festivals of Christmas, Hari Raya, Deepavali, Confucius' birthday, Vesak Day and Lao Zi's birthday": "Society aims to serve singaporeans of all backgrounds" The Straits Times (22 December 2008).

339 Asad Latif, "Warriors at the front line of tolerance" The Straits Times (15 November 2004) (Buddhist Lodge donated a third of its $\$ 3$ million raised fund to Muslim, Hindu and Christian organisations); Yap Kim Hao, "Hongbao giveaway boosts inter-faith cooperation" The Straits Times (14 January 2003) ("Buddhist Lodge sought the participation of Jamiyah Singapore and Hindu Endowments Board in the planning and distribution” of hongbao - red packets containing money); Chin Soo Fang, "Monk's \$100,000 gift to Catholics" The Straits Times (16 May 1999) at 3 (donating to the Catholic Canossian Missions, and other Muslim and Hindu groups). 340 "3,200 Gather in a Festive Feast for All” The Straits Times (15 February 1999) at 1 (Food were blessed by religious leaders from seven major faiths.).

341 Mak Mun San, “Happy meals” The Straits Times (9 November 2003).

342 "Religion Still Relevant, Says President” The Straits Times (19 May 2000) at 3. 
follow suit. ${ }^{343}$ Indeed, Muslim charitable organisations generally do not see conversion as an objective and hence do not have major problems collaborating with non-Muslim organisations. 344

In short, there is hardly any plausible reason why allowing aggressive criticisms of other religions in religious propagation is conducive to social harmony in a religiously pluralistic society. The case study of Singapore indicates the opposite. Indeed, despite the aforementioned studies on Christian attitudes in Singapore, it is interesting to note the subtle but important change in stance by Christian leaders and the NCCS in recent times. The NCCS and other prominent church leaders have now spoken out strongly against insensitive proselytisation ${ }^{345}$ and have provided support for inter-faith religious dialogue and greater inter-faith collaboration in social work. ${ }^{346}$ Further sociological studies will be necessary to determine the cause of this transformation from a previously exclusive and conservative outlook. ${ }^{347}$ However, two factors appear to play a part. First, there is the recognition that this approach is more effective in the context of Singapore's religiously pluralistic society. ${ }^{348}$ Second, and more importantly in the analysis of the appropriate legal regime, increased government pressure under the legal framework of the MHRA has played a part in the change in attitude. ${ }^{349}$ Legal restrictions alone may be insufficient to ensure genuine religious harmony, ${ }^{350}$ but Singapore's experience suggests that they may form a conducive foundation for inter-religious interactions.

343 Zakir Hussain, "Mosques feed 1,000 needy S'poreans” The Straits Times (14 July 2008) (Muslim organisations providing vegetarian option in the distribution of free meals).

344 Enon Mansor \& Nur Amali Ibrahim, "Muslim Organizations and Mosque as Social Service Providers" Lai Ah Eng ed., in Religious Diversity in Singapore (Institute of Southeast Asian Studies, 2008) at 459, 464-470.

345 Edmond Chua, "Christians must respect beliefs of non-Christians, theologian stress" Christian Post (Sing. ed.), (28 April 2010), online <http://sg.christianpost.com/dbase.php? cat=education\&id=787> (last visited 1 February 2013); "What Others Say About the Incident" The Straits Times (10 February 2010).

346 Clarissa Oon, "Talk and let live” The Straits Times (3 February 2010).

347 Supra V.B. See generally Mathew Mathews, "Negotiating Christianity with Other Religions: The Views of Christian Clergymen in Singapore" in Lai Ah Eng ed., Religious Diversity in Singapore (Institute of Southeast Asian Studies, 2008).

348 Edmond Chua, "Bishop says preaches must watch sermon content, presentation" Christian Post (Sing. ed.) (23 September 2010), online: <http://sg.christianpost.com/dbase.php? cat=church\&id=2594> (last visited 1 February 2013); "Christianity: Winning Others or Helping Others Win?” Christian Post (Sing. ed.) (28 June 2010), online: <http://sg.christianpost.com/ dbase/editorial/732/section/1.htm> (last visited 1 February 2013).

349 Mathew Mathews, “Accommodating Relationship: The Church and State in Singapore” in Julius Bautista \& Francis Khek Gee Lim eds., Christianity and the State in Asia (Routledge, 2009) at 193.

350 Li-ann Thio, “Contentious Liberty: Regulating Religious Propagation in a Multi-Religious Secular Democracy” (2010) S.J.L.S. at 513. 


\section{A Tentative Defense for Limited Restrictions}

The limited applicability and veracity of the arguments against proselytisation restrictions highlighted in the preceding analysis do not necessarily justify restrictions on proselytisation, whether in Singapore or elsewhere. The religious liberty of adherents of evangelical religions to proselytise and propagate their faith should always be an important consideration against restrictions of these activities. As argued even by critics of Singapore's measures, the question is one of balance between the individual's right to free speech and religious liberty and the State's interest in the preservation of social harmony. ${ }^{351}$ This article argues that the problem occurs when the contested assumption of religious truth-seeking and the doubtful benefits of religious integration are given undue weight against the restrictions. A more circumspect inspection of the level of restrictions and the harm caused may justify limited restrictions on offensive religious propagation.

First, it is important to distinguish between restrictions on religious propagation and religious switching. The fact that religious propagation is "intrinsically bound" to religious conversion ${ }^{352}$ should not obfuscate the various considerations at play. The freedom to change religion/belief is absolute. ${ }^{353}$ This is unsurprising given the far-reaching effects on individual autonomy arising from restrictions on conversion and the limited and tenacious implications of the rights and interests of others. ${ }^{354}$ Moreover, the inherent double standards in theological arguments for apostasy, where conversion away from other religions is acceptable but not vice-versa, ${ }^{355}$ place such restrictions on

351 Jaclyn Ling-Chien Neo, "Seditious in Singapore! Free Speech and the Offence of Promoting Ill-Will and Hostility Between Different Racial Groups" (2011) S.J.L.S. at 354; Li-ann Thio, "Contentious Liberty: Regulating Religious Propagation in a Multi-Religious Secular Democracy” (2010) S.J.L.S. at 493.

352 Li-ann Thio, "Contentious Liberty: Regulating Religious Propagation in a Multi-Religious Secular Democracy” (2010) S.J.L.S. at 488.

353 Arvind Sharma, Problematizing Religious Freedom (Springer, 2011) at 221; Thomas F. Farr, "The Widow's Torment: International Religious Freedom and American National Security in the 21st Century" (2009) 57 Drake L. Rev. at 862; Kyriakos N. Kyriazopoulos, "Proselytization in Greece: Criminal Offense vs. Religious Persuasion and Equality” (2004) 20 J.L. \& Religion at 169. 354 See Dian Abdul Hamed Shah \& Mohd Azizuddin Mohd Sani, "Freedom of Religion in Malaysia: A Tangled Web of Legal, Political, and Social Issues” (2011) 36 N.C. J. Int’l L. \& Com. Reg. 647, 664-669 (discussing the conversion restrictions in Malaysia).

355 Arvind Sharma, Problematizing Religious Freedom (Springer, 2011); Heather J. Sharkey, "Muslim Apostasy, Christian Conversion, and Religious Freedom in Egypt: A Study of American Missionaries, Western Imperialism, and Human Rights Agendas” in Rosalind I.J. Hackett ed., Proselytization Revisited: Rights Talk, Free Markets and Culture Wars (Equinox, 2008) at 141. 
shaky normative grounds. In this regard, it is important to note that there are no restrictions on religious switching in Singapore, ${ }^{356}$ including restrictions of Muslim apostasy that continued to be enforced in Malaysia and elsewhere. ${ }^{357}$

The relationship between proselytisation restrictions and the absolute right to change religion/belief is more complex. Restricting religious propagation can impede informed religious choice. ${ }^{358}$ One might choose to leave one's original religion if one receives information revealing the deficiencies of one's religion. Restricting the unsolicited supply of this information may arguably delay or even impede changes in religious belief. However, this is a far cry from mandating or coercing a particular religious choice. ${ }^{359}$ Moreover, proselytisation implicates the rights and interests of a third party (i.e., the receiving party) and is often framed as a balance between competing rights between the proselytisers and the proselytised. ${ }^{360}$ Thus, the enquiry concerns the extent of the proselytisation restrictions, where an overly broad restriction would unduly curtail religious liberty without sufficient justification from the competing interests of third parties and the State.

The Singapore official approach towards proselytisation restrictions essentially categorises proselytisation based on two characteristics: whether the religious propagation is solicited and whether the religious propagation involves critical commentary of other religions. The first category - solicited religious propagation without any critical commentary of other religions - is uncontroversial in Singapore and clearly permitted. The second category - unsolicited

356 Jaclyn Ling-Chien Neo, "Seditious in Singapore! Free Speech and the Offence of Promoting Ill-Will and Hostility Between Different Racial Groups” (2011) S.J.L.S. at 365-366.

357 C.f. Jean DeBernardi, “Asia’s Antioch: Prayer and Proselytism in Singapore” in Rosalind I.J. Hackett ed., Proselytization Revisited: Rights Talk, Free Markets and Culture Wars (Equinox, 2008) at 258 ("Although apostasy is not considered to be an offense in Singapore, nonetheless on conversion Singaporean Malay Christians reportedly experience social stigma and ostracism.”).

358 Stephen C. Berkwitz, "Religious Conflict and the Politics of Conversion in Sri Lanka" in Rosalind I.J. Hackett ed., Proselytization Revisited: Rights Talk, Free Markets and Culture Wars (Equinox, 2008) at 216; Li-ann Thio, “Contentious Liberty: Regulating Religious Propagation in a Multi-Religious Secular Democracy” (2010) S.J.L.S. at 510.

359 See Olmedo-Bustos v Chile, Inter-American Court of Human Rights (Ser. C) No. 73 (2001). C.f. Anat Scolnicov, The Right to Religious Freedom in International Law (Routledge, 2011) at 195-196 (disagreeing with the court's narrow interpretation of right to religious belief).

360 Li-ann Thio, “Contentious Liberty: Regulating Religious Propagation in a Multi-Religious Secular Democracy” (2010) S.J.L.S. at 493; Thomas F. Farr, “The Widow's Torment: International Religious Freedom and American National Security in the 21st Century" (2009) 57 Drake L. Rev. at 862 . 
distribution of materials promoting the merits of one's religion - is allowed as well. ${ }^{361}$ The third category - unsolicited proselytisation that denigrated other religions - is the redline taboo as reflected in the criminal sanctions in the Ong Kian Cheong case and the Andrew Kiong case and the frequent exhortations by the government. The fourth category - solicited religious propagations that are critical of other religions - appears to be prohibited in the Pastor Tan and Pastor $\mathrm{Ng}$ incidents.

The correct balance is arguably struck in the context of Singapore if the restrictions on proselytisation are limited only to the third category where the risk of religious tension is the greatest. Unsolicited religious propagation is permitted, ensuring that religious adherents can fulfill their duty to spread their faith. Moreover, solicited religious propagation involving critical commentary of other religions remains unrestricted. Once recipients of unsolicited promotion of a particular religion are interested to learn more of that particular religion and proceed to approach either the propagator or the places of worship of that particular religion for more information, the circumstance shifts away from the restrictive category of unsolicited religious propagation. Of course, the limitation on critical comparisons of other religions in unsolicited religious propagation is certainly a non-trivial restriction, but the offense to the unwilling recipients and the corresponding religious tension are countervailing considerations as well. As noted above, unsolicited, offensive religious propagation is likely to aggravate fault lines between different religious communities, especially for the receiving religious community. In addition, the ability to conduct such religious propagation provides little "integration" effect for the propagating religious community. In this regard, this article argues that there is sufficient normative justification for the prohibition of unsolicited "offensive" religious propagation sanctioned the Ong Kian Cheong case and the Andrew Kiong case, notwithstanding the potential jurisprudential deficiency in the courts' interpretation of the legal provisions. ${ }^{362}$

In contrast, the extension of restrictions to the fourth category of religious propagation in the Pastor Tan and Pastor Ng incidents is problematic. Although no concrete legal sanctions were levied on the two pastors, the public involvement by the ISD made it abundantly clear to the two pastors and the public at large that such actions were not permitted and were liable to attract some forms of punitive sanctions. However, the justification for prohibiting such speeches is considerably weaker than the Ong Kian Cheong and Andrew Kiong cases. In both

361 Supra IV.A.

362 See Jaclyn Ling-Chien Neo, "Seditious in Singapore! Free Speech and the Offence of Promoting Ill-Will and Hostility Between Different Racial Groups” (2011) S.J.L.S. at 361-364. 
the Pastor Tan and the Pastor Ng incidents, the "offensive" religious speeches were made on their respective church premises to voluntary audiences. The critical commentary of other religions, while arguably insensitive and perhaps inaccurate, appears to simply be part of religious propagation toward persons who are clearly interested in knowing more about how the propagated religion is different from (and superior to) other available religions. There is no attempt at unsolicited proselytisation. Indeed, according to the distinction established by the government, both incidents should fall within the permitted realm of religious propagation to "interested" persons. When recipients are interested in conversion, the risk of offense and religious tension is significantly reduced. The right to religious belief - especially the right to change religions - is more directly and aversely implicated. Substantially more leeway in the content of the speech, including critiques of other religions, should be afforded in these circumstances.

In this respect, Li-ann Thio is perhaps correct to argue that the bluntness of legal sanctions makes these sanctions poorly equipped to address these types of cases, where only the vague "soft constitutional norms" restricting insensitive religious propagation are involved. ${ }^{363}$ Rather, a calibrated political response, such as that demonstrated by the government in the Pastor Tan incident, which involves collective resolution through the religious communities ${ }^{364}$ would be preferable approach to achieve true solidarity. ${ }^{365}$ This "relational constitutionalism," which looks beyond strict reliance on legal norms and sanctions, is arguably more effective for cultivating true solidarity within the polity. ${ }^{366}$ Nonetheless, as noted above, one must not lose sight of the fact that the calibrated political resolution of the Pastor Tan and Pastor $\mathrm{Ng}$ incidents is only possible with a backdrop of legal provisions that grant the executive branch of the government broad discretionary power in matters of religious harmony.

Thus, although this article argues that relatively limited and well-defined restrictions on unsolicited critiques of others' religions are arguably justified in the context of Singapore, this article is ambivalent about restricting critical commentary of other religions that is directed at a voluntary interested audience

363 Li-ann Thio, "Relational Constitutionalism and the Management of Religious Disputes: the Singapore 'Secularism with a Soul' Model” (2012) Oxford J. L. and Religion at 19-21; Li-ann Thio, "Contentious Liberty: Regulating Religious Propagation in a Multi-Religious Secular Democracy” (2010) S.J.L.S. at 504-505.

364 Li-ann Thio, “Contentious Liberty: Regulating Religious Propagation in a Multi-Religious Secular Democracy” (2010) S.J.L.S. at 505.

365 Ibid., at 513.

366 Ibid. 
and does not involve religious hate speech. These types of speeches certainly do not promote religious harmony, but imposing and/or threatening legal sanctions unduly curtails the religious liberty of both the speakers and their voluntary audience. The successful internalisation of soft constitutional norms ${ }^{367}$ to achieve positive outcomes in both the Pastor Tan and Pastor $\mathrm{Ng}$ incidents should not distract from the fact that the underlying legal backdrop is problematic.

\section{Conclusion: Desperately Seeking overlapping CONSENSUS}

The tendency of proselytisation restrictions to be regarded as simply capture of the State's coercive power by politically dominant religious majorities to serve their own interests has prevented a more circumspect analysis of such restrictions. Departing from this questionable practice, the atypical case of Singapore's restrictions highlights the limited applicability of religious truthseeking as a normative principle. Although it is true that "evangelism is built into the soul of many religions,"368 "many" is not "all." "Many" may also not even mean "majority." Where this religious truth-seeking emphasis is not shared by the majority of the religious outlooks in a polity, a tentative case can be made for limited restrictions on offensive religious propagation. This article does not suggest that Singapore's regime is an unqualified success or should be replicated as a normative model. Although restrictions on unsolicited critiques of other religions can be justified without the otherwise dominant consideration of religious truth-seeking, there is no coherent normative principle restricting mere critical commentary of other religions directed at a voluntary audience.

On a broader note, the case study of Singapore highlights the challenge in finding an appropriate approach toward religious liberty issues such as proselytisation. One possible solution in dealing with plurality is to achieve broadly supported common grounds or an overlapping consensus. An overlapping consensus, if attained, may provide a foundational constitutional principle to frame

367 Li-ann Thio, "Relational Constitutionalism and the Management of Religious Disputes: the Singapore 'Secularism with a Soul' Model” (2012) Oxford J. L. and Religion at 19-20.

368 Li-ann Thio, “Contentious Liberty: Regulating Religious Propagation in a Multi-Religious Secular Democracy” (2010) S.J.L.S. at 493. 
the church-state relation in a polity. ${ }^{369}$ The classic example is the U.S. constitutional prohibition on the state establishment of religion, which is supported by both the religious rationales of the Evangelical Christians and the secular considerations of Enlightenment Lockeans. ${ }^{370}$ However, the challenge of finding such an overlapping consensus is fraught with greater complications in a truly religiously pluralistic society such as Singapore, where the diverse religious outlooks of different world religions all enjoy significant population representation.

In this regard, even the acceptance of the premise that religion is good thing $^{371}$ is insufficient, notwithstanding the tendency to lump all religious believers together to form an ostensible majority of "more than $80 \%$ " of Singapore's population. ${ }^{372}$ Different religions have different conceptions and assumptions about the purpose of religion. In the particular area of religious propagation and its underlying assumption of the importance of religious truthseeking, there is genuine divergence among the different religious communities in Singapore. There is no easy overlapping consensus even if we are prepared to exclude the $17 \%$ of Singapore's population with no religious affiliation. ${ }^{373}$

369 See Andrew Koppelman, "Corruption of Religion and the Establishment Clause" (2009) 50 Wm. \& Mary L. Rev. at 1843 (discussing overlapping consensus as a political mechanism to cope with religious pluralism). See generally John Rawls, "The Idea of an Overlapping Consensus" (1987) 7(1) Oxford J. Legal Stud. 1.

370 Andrew Koppelman, “Corruption of Religion and the Establishment Clause” (2009) 50 Wm. \& Mary L. Rev. at 1875-1876; Julia K. Stronks, Law, Religion, and Public Policy: A Commentary on First Amendment Jurisprudence (Lexington Books, 2002) at 40-41.

371 Li-ann Thio, "Contentious Liberty: Regulating Religious Propagation in a Multi-Religious Secular Democracy” (2010) S.J.L.S. at 489 ("[Religious propagation] may be justified on several grounds, resting on the premise that law considers a religion a good thing, deserving protection.”). 372 E.g., Li-ann Thio, "Between Eden and Armageddon: Navigating 'Religion' and 'Politics' in Singapore" (2009) 2009 S.J.L.S. 265, 379 ("this [exclusion of religious perspective in public debate] would discriminate against the more than $80 \%$ of Singaporeans with Singaporeans with religious affiliation in voting, taking part in elections and debating public issues."); Vincent Chia Wei Meng, "Govt should consider carefully the moral value system of the majority before making decision" The Straits Times (26 July 2007), Online Forum ("According to Statistics Singapore, the majority of Singaporeans are not atheists, agnostics or secular humanists without religious affiliations... Within our multi-religious society, a common consensus on this issue can only be achieved by being mindful of the morality of the religious majority.”).

373 For two recent discussions on the political and legal status of non-religious persons, see Nelson Tebbe, "Nonbelievers" (2011) 97 Va. L. Rev. 1111 (arguing for a polyvalent approach towards non-believers where the courts' handling of non-believers under religious freedom law should be context sensitive towards the different values and considerations animating the particular law); Caroline Mala Corbin, "Nonbelievers and Government Speech" (2012) 97 Iowa. L. Rev. 347 (arguing that government religious speech violates the Establishment Clause as such speech undermines the equality and liberty of nonbelievers). 
Religious truth-seeking, premised upon a distinct religious worldview, is not a magic bullet in grappling with religious plurality in the interpretation of religious liberty.

Acknowledgement: The author is grateful for the reviewer's insightful comments and suggestions, and thanks Sharon Tam Suet Yan for her excellent research assistance. All errors are mine alone.

Research Funding: This research is generously supported by University of Hong Kong's Seed Funding Programme. 
Brought to you by | University of Hong Kong Libraries Authenticated | 147.8.31.43

Download Date | 7/15/14 4:56 AM 